\title{
Service Triads: \\ A Research Agenda for \\ Buyer-Supplier-Customer Triads in Business Services
}

Finn Wynstra ${ }^{1}$, Martin Spring ${ }^{2}$, Tobias Schoenherr ${ }^{3}$

\begin{abstract}
Service triads, in which a buyer contracts with a supplier to deliver services directly to the buyer's customer, represent an emerging business model. This special issue is dedicated to this theme. To set the context, in this lead article, we first define service triads, both as a phenomenon and a research topic. We then provide a review of different strands of existing research and various theoretical frameworks that can inform our study of service triads. This culminates in an outline of a research agenda that can guide future study. As such, this paper not only introduces the articles in the special issue, but is also intended as a point of reference and motivation for further work on service triads, and on triads in general.
\end{abstract}

Keywords: Service triads; Buyer-supplier-customer triads; Services; Networks; Empirical research; Research agenda

\footnotetext{
${ }^{1}$ Rotterdam School of Management, Erasmus University - PO Box 1738, 3000 DR Rotterdam, Netherlands; fwynstra@rsm.nl.

${ }^{2}$ Lancaster University Management School- Bailrigg Lancaster, LA1 4YX, United Kingdom; m.spring@lancaster.ac.uk.

${ }^{3}$ Michigan State University, Department of Supply Chain Management, Eli Broad College of Business, Michigan State University, 632 Bogue St., Room N370, East Lansing MI, 48824, USA, schoenherr@broad.msu.edu.
} 


\section{Introduction}

The growth in specialization and outsourcing among firms has given rise to an operations and supply landscape that is increasingly based on networks rather than large vertically integrated firms (Buhman et al., 2005, Hayes, 2008). Firms focus on what they can do best, and outsource the remaining tasks to outside providers (Holcomb and Hitt, 2007). This involves in many instances key service operations (Sako, 2006). A large share of these services becomes part of the buying organization's value proposition to its customers: they are purchased by one organization from another, but delivered to a third party - the customer. These services are being referred to as 'frontend' services (Balakrishnan et al., 2008) or 'component' services (Van der Valk et al., 2009).

For example, if a software company outsources its helpdesk services to a third-party call-center, the primary service interaction is between the customer and the call-center, not between the customer and the software company, even though the customer has a contractual relationship with the software company. Other instances include manufacturers of capital equipment using maintenance service providers to work directly with end-users, as well as many third-party logistics settings. In the public sector, public transportation service providers often operate under specific government contracts (concessions) to provide a service to the general public.

The ensuing relationships between buyer, supplier and the (buying organization's) customer can be viewed as a 'service triad', in which a buyer contracts with a supplier to deliver services directly to the buyer's customer ( $\mathrm{Li}$ and Choi, 2009, Niranjan and Metri, 2008). The basic service triad is shown in Figure 1. It consists of the buyer, supplier and customer. Importantly, such service triads entail a structure of inter-organizational relationships that is fundamentally different to that encountered in the more linear supply chains especially observed in manufacturing. The critical point about the triadic structure is that each actor has a direct connection with the other two; such connections may be constant or intermittent. Some triads' service delivery activities are only mobilized rarely - maybe never. For example, car repair shops are only brought into contact with the policy-holder (customer) if the customer has an accident that is covered by his/her policy with the insurance company (buyer). Nonetheless, in the event of a claim, there is direct supplier-customer interaction.

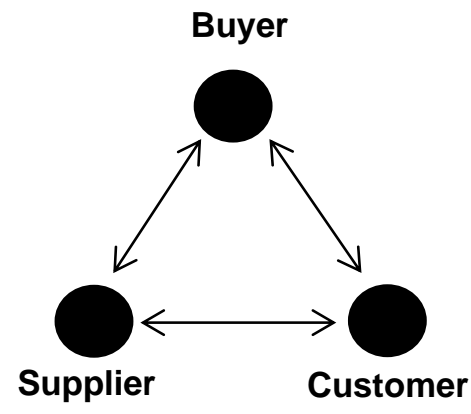

Figure 1. The service triad 
In the examples above, the research focus is often on the buyer as the active player. But similar configurations can be observed when customers play an initiating role, using buyers (intermediaries), for example in the form of project management firms, to facilitate their access to suppliers (service providers) (Flowers, 2007, Mabert and Schoenherr, 2001, Schoenherr and Mabert, 2003).

Although inter-organizational triads are not an entirely new research topic, there is a growing interest in recent times, particularly within the operations management and supply chain management (OM-SCM) field. There, the interest in triads received a strong boost around 2008-2009, with various conceptual papers and essays published on the Operations \& Supply Management Forum (set up by the editors of the Journal of Operations Management), and a debate between Choi and Wu (2009a) and Dubois (2009) in the Journal of Purchasing and Supply Management. In this latter debate, Choi and Wu argued: "We need to study how in a network, a dyad is affected by another dyad. Therefore, to study a network, studying triads becomes imperative. ... Simply, dyads are inadequate in capturing the interactive nature inherent in a network." (2009a: 265).

Against the background of this call for more OM-SCM research on triads, we suggest that service triads merit specific attention. Because their primary operations involve a service, particular issues come to the fore. Critically, and in contrast to many other forms of triads, the supplier needs to have direct exchange with the customer, in order to deliver its service. For this delivery, the supplier depends on inputs, typically from customers (Sampson and Froehle, 2006) but, in a triad setting, quite often also from buyers. A service triad is therefore different from the bidirectional service supply chain' (Sampson, 2000), where the supplier only has one counterpart to rely on for inputs, i.e. a buyer that is also the customer of the service. Thus, triads provide a critical context to better understand the nature and relative importance of various inputs for the service process. The notion of an inherent supplier-customer exchange also highlights the fluctuating role that a buyer may have in such service triads. For instance, how can a buying organization, reliably and efficiently, monitor service quality if it is not involved in the actual service delivery, especially when this quality is highly dependent on the interaction between supplier and customer?

Such service triads, however, have not received much specific coverage in prior research. A few exceptions exist. For example, service triads have been studied using social network theory (Li and Choi, 2009), drawing attention to the dynamics of relationships between the three triad members as an outsourcing arrangement is established. Nevertheless, recent discussions suggest that there are opportunities to extend the study of triads using other theoretical approaches, from within OM-SCM and from outside our discipline (Choi and $\mathrm{Wu}, 2009 \mathrm{c}$ ).

This special issue is a response to that call, and the present lead article introducing the special issue has three specific objectives. The first objective is to define service triads, both as a phenomenon and a research topic. The second objective is to provide a review of different strands of existing research and various theoretical frameworks that can inform our study of service triads. Outlining a research 
agenda is the third main objective. As such, the article not only provides a background for the articles in the special issue, but it is also intended as a point of reference and motivation for further work on service triads, and on triads in general.

While previous research has begun to apply the notion of triads within the domain of operations management, primarily focusing on structural aspects of triads, the current article is aimed to help advance our understanding of the impact of the structure and dynamics of service triads on specific OM-SCM issues, such as service risk management; quality management in services; and service capacity management. In other words; we intend to stimulate research and the development of theories on OM-SCM phenomena in service triads, rather than theory development and testing regarding the (dynamic) structure of triads in service supply chains. Further research on OM-SCM phenomena in service triads also would help, more broadly, fill the gap in research on business-tobusiness services (Ostrom et al., 2010).

In the following section, we discuss OM-SCM research on triads. Section 3 discusses triad studies in management research and (other) social sciences. Section 4 reviews the distinctive features and various forms of service triads. In section 5 we outline a research agenda along three dimensions: specific topics for research in service triads, alternative theoretical approaches, and methodological aspects. Section 6 introduces the papers in this special issue, with section 7 offering some concluding thoughts.

\section{OM-SCM research on triads}

For our review of prior literature, we examined (not just service) triad studies from the OM-SCM domain - and from the wider area of management and organization research. These studies were collected in two ways. First, we searched the Web of Science portal for journal articles in the field of management, using the term 'triads' (no year limits). To verify that we did not miss any relevant articles, we checked the reference lists of the initial set of articles. We then manually selected the relevant articles from these two sets that represented studies focusing on inter-organizational triads (e.g. leaving out studies that dealt with the US-Europe-Japan triad). Secondly, we added to this set conference papers and dissertations with which we were already familiar or came across in reference lists. We selected publications that presented a substantial discussion of triads, omitting those that only mentioned them in passing.

This resulted in a set of 30 publications, which are described in Appendix 1. While we cannot review each of these studies in depth here, the appendix provides the most salient descriptors. In the main text, we select for discussion those studies that seem to be important milestones in triad research.

\subsection{Triads}


Most existing OM-SCM research on triads is concerned with the triad formed by the buyer and two upstream suppliers in a manufacturing context (Figure 2). It is typically concerned with how the buyer can influence the relationship between the suppliers. Prominent among this research is the work of Choi, Wu and colleagues. Their first study (Choi et al., 2002) began from the observation that, as firms reduce the number of direct suppliers that they use, they can and do seek more actively to influence the relationships between suppliers. It examines three archetypes of supplier-supplier relationships - competitive, cooperative and 'co-opetitive' - and develops several propositions regarding the effect of each of these on the outcomes both for suppliers and for their customer.

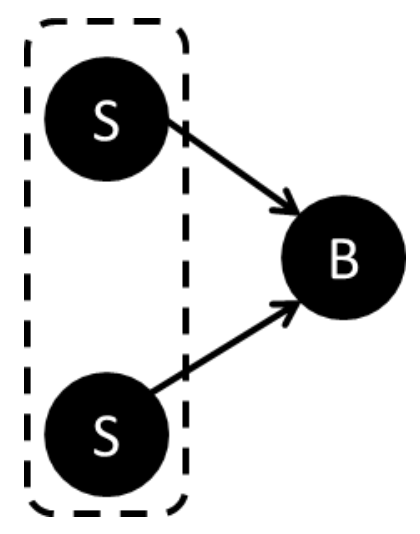

\section{Figure 2. Buyer-supplier-supplier triad}

$\mathrm{Wu}$ and Choi (2005) develop this further by focusing on the active shaping of the supplier-supplier relationship by the buyer; the paper presents five archetypes, characterizing the different approaches of the buyers, and develops propositions, most of which concern supplier-supplier relationships and their effect on performance. The paper also signals the aim of this program of research, namely to develop theory - effectively a contingency theory - regarding the ideal types of supplier-supplier relationships from the buyer's point of view, depending on the product type and the buyer's strategy. Choi and $\mathrm{Wu}$ (2009c) again develop archetypes of triadic relationship patterns, this time using balance theory (Heider, 1958) and the social network concept of structural holes (Burt, 1992). Wu et al. (2010) seek to examine empirically whether buyer-induced supplier-supplier 'co-opetition' affects performance. It finds, unexpectedly, that such co-opetition is correlated with worse supplier performance, but is ambivalent as to whether the poor performance is due to the firms' resources being overstretched by the requirement to co-operate, or whether the requirement to co-operate arises from the supplier firms' having exhibited poor performance, i.e. the reverse causality. In any case, it demonstrates empirically that buyers' efforts do have an effect on supplier-supplier interaction.

Another notable study in this vein is by Dubois and Fredriksson (2008). They propose the notion of 'triadic sourcing', a strategy which seeks to engender interdependencies and cooperation between potentially mutually competitive suppliers. Triadic sourcing sees the buyer encouraging deep 
interdependence during product development, sourcing, and through other mechanisms, e.g. using one another's production capacity for similar products. The case study evidence suggests that triadic sourcing can provide efficiency, flexibility and innovation.

Apart from the substantive findings of these papers, it is also useful to reflect on the way in which the triadic form as such is brought into the studies (this is of particular relevance when we consider methodological issues in Section 5). In Choi et al. (2002), specific reference to triads is only made in the last few paragraphs: although the graphical representations of the archetypes show three firms, this seems to be used to represent the nature of relationships among multiple suppliers, however many there may be. Wu and Choi (2005), in contrast, adopt an explicitly triadic view from the outset. Nevertheless, data were collected on suppliers beyond the triad where necessary and, of their eight 'triad' archetypes, two are described and represented as involving more than three firms. So, although triads are the central concept, making the data collection and analysis feasible and presentation more compelling, there is still some flexibility in the triadic framing of the work. Also, as noted, most of the propositions are concerned with the ensuing supplier-supplier relationships, rather than triadic phenomena, and the 'naming' of the archetypes ('coach', etc.) refers to the role of the buyer.

By the time we reach the conceptual study in Choi and $\mathrm{Wu}(2009 \mathrm{c})$, however, the triadic formulation is more central: while still writing of the triad as 'the next logical step' after the dyad (which still suggests tractability rather than conceptual necessity as the motivator), the paper adopts a theory of balanced triads based on Heider (1946). Importantly for the later discussion on method, Choi and $\mathrm{Wu}$ (2009c) develop theory about triads (more specifically, about their balance): in contrast, prior work developed theory about dyads as affected by their existing in triads. Then, in Wu et al. (2010), the focus returns to the management of supplier-supplier relationships by buying firms (as in Wu and Choi (2005)) and, as in Choi et al. (2002), is rooted in the game-theoretic idea of 'coopetition'.

Several triad studies, within the OM-SCM field, have thus focused on buyer-supplier-supplier triads. In addition to studies of buyer-supplier-supplier triads, there have been a few studies of other types of triads. Bastl, Johnson and Choi (2013) make a distinction between two-tier and three-tier triads. Two-tier triads involve two actors who essentially perform the same role vis-à-vis the third actor, i.e. they involve two suppliers (as discussed above) or two customers. The OM-SCM literature does not encompass any specific studies on triads with two customers, but other management research disciplines do (see Appendix 1).

Three-tier triads involve actors that perform different roles in the overall supply 'chain'. Typically, these latter types of triads involve an actor that is performing two different roles; a supplier role in relation to one actor, and a customer role in relation to the other actor. These three-tier triads are similar to our buyer-supplier-customer triads, and the OM-SCM literature contains just a few studies of such triads (in manufacturing). Mena et al. (2103) study power and relationship stability between customers, suppliers and second tier suppliers. One of the central propositions derived from their 
exploratory studies is that a triad (i.e. a setting where the customer also has a direct relation with the second tier supplier) offers greater perceptions of stability, but that it also requires larger management effort. Rossetti and Choi (2008) investigate the process of disintermediation, where a supplier bypasses the buyer to directly serve a customer. Their study, in aircraft manufacturing, finds that supplier-buyer goal incongruence increases disintermediation.

Comparing the buyer-supplier-customer (BSC) service triad (Figure 1) and the buyer-suppliersupplier (BSS) triad (Figure 2), there is one key difference. In the service triad, exchange is taking place between the supplier and the customer, not between the supplier(s) and the buyer. As a consequence, exchange in and the governance of the other relations is also different. We now turn to a specific discussion of service triads.

\subsection{Service triads}

It is only relatively recently that service triads have been explicitly identified as an object of study. In contrast to manufacturing triads, as we have seen, service triads typically involve three distinct entities, i.e. a buyer, a supplier and a customer (as opposed to for example one buyer and two suppliers in a manufacturing context). At this point, it is also worth noting that there may be multiple suppliers of services to a buyer, just as there are multiple supplier of components in 'classic' manufacturing triads. However, our specific interest here is in the buyer-supplier-customer triad, and any buyer may be involved in several of these.

Within the domain of service triads, Li and Choi (2009) focus on shifting relationship structures, and in particular on the position of the (services) buyer vis-à-vis that of the supplier and customer. In services outsourcing, the 'bridge' position of the buyer between supplier and customer, providing information and monitoring benefits, may decay as the supplier comes into direct contact or interaction with the customer, leading to erosion of those benefits. According to Li and Choi (2009), investing in communication with supplier and customer will yield information on how the supplier performs, curbing opportunistic behavior, and enabling the buyer to better control performance.

Finne and Holmström (2012) analyze the process where subsystem suppliers bypass system integrators (buyers) and directly build relations with customers. Their (single case) study demonstrates that the supplier's service capabilities are contingent on access to the field service sites and installed base information, which require a relationship with the customer. Triadic cooperation between supplier, buyer and customer improves the value to the customer "by improving service quality and aligns the interests and capabilities of supplier and intermediary" (Finne and Holmström, 2012: 30).

The suitability of different forms of contracts for the buyer-supplier and buyer-customer relation are examined by Van der Valk and Van Iwaarden (2011); then, Van Iwaarden and Van der Valk (2013) use the same type of triads to investigate the conditions for service delivery quality control in different phases (e.g. service design, service delivery). Similarly, Menor and Johnson (2012) elaborate 
on various aspects of service quality and the different roles that service triad actors have in managing quality. Holma (2012) investigates the interpersonal interactions between a buyer (travel agent), customer (client) and suppliers (e.g. hotels) of travel services.

Others examine all or part of the service triad issue, but only implicitly. Axelsson, Van der Valk and Wynstra develop and test a typology of business services, which includes what they label 'component services' - again, those services delivered directly to the end customer - but their focus is primarily on the management, by the buying firm, of its relationship with the supplier (see, for instance Axelsson and Wynstra, 2002, Van der Valk and Wynstra, 2012, Wynstra et al., 2006). In other words, the triad is implicit; the aim of the study is to inform the dyadic relationship between buyer and supplier. Balakrishnan et al. (2008) examine the circumstances under which buying firms should outsource 'front-end' services, i.e. those that are delivered by a supplier directly to the customer - in other words, the very scenario we outline above - but, although they use the service OM concept of customer contact (Chase, 1981) in relation to the supplier-customer link, they do not take any account of the customer-buyer link in the triad. Finally, Peng et al. (2010) use an explicitly triadic approach to study maintenance services, but do not develop insights specific to services.

In recent years, studies have also emerged that investigate the dynamics of triads that involve at least two actors from one and the same organization. Typical examples are studies of a supplier and two units within the buying organization: the purchasing department and the internal client. Especially, in the context of service procurement we see such (partly internal) triads being studied (Andersson-Cederholm and Gyimóthy, 2010, Tate et al., 2010).

Thus, by and large, the research on triads within OM-SCM has focused on quite a variety of triad structures, although the handful of studies that deal with service triads have investigated buyersupplier-customer triads. However, most service triad studies have focused on the process of relationship formation and dissolution in triads-much like most other management research on triads. Very few studies have dealt with typical OM and SCM phenomena in (service) triads, such as capacity management or quality control, with some (recent) exceptions.

\section{Triad studies in management research and the social sciences}

So far we have examined work from OM-SCM. In this section, we briefly discuss work on triads from other areas of management and organization studies (see Appendix 1). We also provide a short review of theoretical approaches from the social sciences that have informed triad research.

\subsection{Triad research in management and organization studies}

In the early 1990s, researchers from the so-called 'Industrial Marketing and Purchasing' (IMP) group were, to our knowledge, the first within management research to explicitly identify triads within business networks as an object of study (Havila, 1996, Havila and Sandström, 1993, Kardane and Salle, 1992, Laage-Hellman, 1989, Pardo and Salle, 1994, Smith and Laage-Hellman, 1992). The 
IMP work was influenced by, among other things, Cook and Emerson's (1984) analysis of exchange relationships (see below). Building on this foundation, Smith and Laage-Hellman (1992) argue that some form of data reduction is necessary to make it possible to analyze networks. As such, they take the triad as their building block for analyzing larger networks, and develop a typology of different transition patterns, exploring how a focal firm can seek to transform its relationships within a triadic structure.

Central to the network approach of the IMP Group is the proposition that relationships are not just an affair between two firms or actors, but that these relations are also affected by and affect the relations of several other actors (Anderson et al., 1994). The network model is voluntaristic rather than deterministic; firms can choose how to act, but the possibilities are determined by the often longlasting relations they have with specific customers, suppliers, competitors, producers of complementary goods, customers' customers, etc. These relations also form the basis and means for change. The network approach has extensively studied such interdependencies with regard to the exchange process between actors, which we return to below.

Other management and organization studies specifically examining triads are rare. Madhavan et al. (2004) examine the circumstances under which a triad of three 'co-opetitors' will become transitive, i.e. each of the three members becomes directly connected to the others. They argue that there are two tendencies that affect the degree to which a triad is transitive: clustering, in which the triad is extended beyond three members without becoming transitive, so as to access a wider set of counterparts and their resources, and countering, where the triad becomes transitive so as to block the potential advantage of the one actor that is linked to the two others.

Lazzarini et al. (2008) examine a setting and associated questions very similar to those in the Choi$\mathrm{Wu}$ studies: the interaction between supplier-supplier and buyer-supplier links in the automotive sector. As is typical in the strategic management literature, these are described as 'alliances', even though they actually cover a wide range of forms and degrees of interaction. The study finds that stronger buyer-supplier links deter strong supplier-supplier links, but that this relationship depends on the level of technological uncertainty. This contextual variable might have implications for the study of service triads.

Finally, Wuyts et al. (2004) study complex product provision (computer networks). Most of their study focuses on (using the terminology adopted in the present paper) the relationships between buyer-supplier links and customer-buyer links, but they also consider the effect of supplier-customer links on customer-buyer links. However, the link between the customer and supplier is one of 'contact' rather than one of exchange or service provision, and is seen mainly as a means of attenuating the risk of opportunistic behavior arising from strong ties between supplier and buyer.

In sum, although these studies do not treat service triads as we have defined them, they do introduce further parameters of interest, including the notion that triads are part of greater networks and represent a more manageable unit of analysis for their study. Further, while the associations 
among firms are voluntary, triad dynamics are influenced by existing structures (e.g. the relative tie strength among the three actors), objectives (e.g. the desire to prevent opportunistic behavior) and environmental contingencies. In addition, support for the transitivity of triads was found, suggesting the tendency for each firm to have direct ties with the remaining two players in the triad. These parameters seem to be essential in the further study of triads.

\subsection{Triad theory from the social sciences}

Triad and service triad research in OM-SCM has also been informed by a number of theoretical perspectives from outside management and organization studies. While these perspectives are concerned, above all, with the connections and relationships between entities, usually people, they have been adopted because they provide possible ways to think about the phenomena arising from the triadic form per se.

\subsubsection{Roles in interpersonal triads}

Simmel, a sociologist and philosopher, studied many things, but here it is his work on triads in interpersonal relationships that is of immediate relevance (Simmel, 1950). He saw the shift from dyad to triad as a fundamental transformation, and identifies three possible roles for the 'third member' of a triad. First is the mediator, who acts impartially, quells conflict between the other two members, and perhaps ensures the triad's continued existence. The second is the tertius gaudens, where a member of a triad exploits the position of being connected to the other two members, who are not connected directly to one another. The third is the 'divide and rule', where the third member deliberately foments conflict between the other two, in order to further his/her own interests.

\subsubsection{Balance theory}

Balance theory is rooted in the psychology literature (Heider, 1946, 1958), and argues that individuals seek 'cognitive consistency' (Kilduff and Tsai, 2003: 42) ${ }^{4}$ in their relationships with others. More specifically, "people prefer balanced relationships; for example, they prefer their friendships to be reciprocated, and for their friends to be friends with each other" (Kilduff and Tsai, 2003: 42). Davis (1963) formalizes these ideas in structural terms and develops a number of implications for inter-personal relationships within organizations. Balance theory has been adopted in a recent study of inter-organizational triads (Choi and $\mathrm{Wu}, 2009 \mathrm{c}$ ), but it should be noted that the original conception and analysis of balance was all at the interpersonal level. It is also noteworthy that, in its final paragraph, Davis' paper comments:

"Despite the wide range of topics covered by the theory it is not advanced as a general theory of interpersonal relations but as a theory of one major component. It is suggested that a general theory of inter-personal relations must consider, in addition to balance,

\footnotetext{
${ }^{4}$ More generally, this section draws on Kilduff and Tsai (2003).
} 
the exchange process and the effects of competition for scarce values." (Davis, 1963:

461)

Even for inter-personal relationships, then, it is acknowledged that other factors may override the desire for balance. Kilduff and Tsai (2003) further suggest that Larson's widely-cited paper on dyadic relationships (Larson, 1992) reflects an extension of balance theory to the inter-organizational level. But it does not make any explicit link to the theory, nor does it extend its analysis beyond the dyadic level, an extension which is fundamental to balance theory in the social psychology literature.

\subsubsection{Social network theory}

Social network theory is an obvious potential approach for studying triads, dealing as it does with the structure and patterns of interaction between actors in networks. Indeed, the work of Burt (2002) has directly informed service triad research by $\mathrm{Li}$ and Choi (2009). The social network literature is huge and, particularly since around 2000, growing exponentially (Borgatti and Halgin, 2011); a vast array of concepts and techniques have been developed. As such, no attempt will be made here to review the literature in detail. Rather, we will briefly examine some key ideas, and comment on their applicability and relevance.

Social network theory has its origins in the study of patterns of interactions among individuals in social relations; indeed, the vast majority of existing research is concerned with the analysis at the inter-personal level. One of the most celebrated examples is Granovetter's notion of the 'strength of weak ties' (Granovetter, 1973), which suggests that strong ties (e.g. close friendships) between individuals tend to result in connections with further similar people holding similar ideas and, hence, that weak ties (e.g. passing acquaintances) are more likely to lead to innovative ideas. A further influential scholar in management and organization studies is Burt (1992). He is noted, above all, for his work on structural holes, which are 'gaps' in connections between different social networks that offer opportunities for individuals who can bridge the gap and link the two otherwise disconnected networks together. According to Borgatti and Halgin (2011), Granovetter and Burt study similar issues but, whereas Granovetter's emphasis is on the nature (strength/weakness) of the tie between individuals, Burt's focus is on its very existence. Moreover, Burt portrays a more strategic and deliberate process of managing network position, whereas Granovetter's view is more serendipitous.

It is clear that aspects of social network theory can be applied to inter-organizational analysis. One form of this is to study networks of individuals who span multiple organizations, in order to understand how these inter-personal networks may affect inter-organizational outcomes. It is quite a different perspective (although potentially related) to treat organizations themselves as the actors who form nodes in a network. Some aspects of social network analysis can be translated from the interpersonal level to the inter-organizational level - arguably, for example, structural concepts such as 'structural holes'. Some, however, cannot: for example, the ways ties between actors are 
characterized (e.g. 'is a friend of'). In some cases these boil down to the fundamental capacities of the type of actors (human or non-human) being considered. As Borgatti and Halgin put it:

"Of course, it should be noted that different kinds of nodes have different capabilities, which needs to be taken account of in generating the auxiliary theorizing that links model outcomes to such outcome variables as, say, performance or creativity. For example, when an individual hears two bits of information, he has a fighting chance of integrating them, but when a firm hears two bits of information, it may be different parts of the organization that house them, and the bits may never come together in the same space to be integrated." (Borgatti and Halgin, 2011: 1177)

Borgatti and $\mathrm{Li}$ (Borgatti and $\mathrm{Li}, 2009$ ) provide a full discussion of the applicability of social network analysis to supply chain management. By its very existence, the paper clearly indicates faith in the potential of this approach; at the same time, Borgatti and $\mathrm{Li}$ once again signal the need for caution in transposing properties of human beings, such as 'cognitive dissonance', to non-human entities such as firms.

\subsubsection{Triads in exchange relations}

Cook and Emerson's studies of exchange networks contrast in many ways with what has gone before in this section, one of which is especially relevant. That is, they define relationships as those involving commercial exchange, rather than mere interaction. This then provides a basis for the examination of indirect effects such as those of interest in triad studies:

"Two exchange relations are connected to the extent that exchange in one relation is contingent, positively or negatively, upon exchange in the other relation." (Cook and Emerson, 1984: 3)

Thus, we would not study relationships as strong or weak, trusting or adversarial, but narrow our focus down to whether (and perhaps to what extent) they entail commercial exchange (Easton and Araujo, 1992). This is particularly relevant for buyer-seller relationships between firms and so, not surprisingly, Cook and Emerson's work provided an important basis for the IMP research stream, as introduced above (e.g. Anderson et al., 1994).

In service triad studies, then, adopting Cook and Emerson's focus on exchange, we should at least make it explicit to which extent each of the triadic relations involve commercial exchange. For instance, does the buyer contract with and pay the supplier? Or are the services paid for directly by the customer, and does the buyer only pre-select (provide a license to) the suppliers? Understanding such details of the exchange relationships helps understand the connections between relations, and the relative positions of the actors in the triad.

\subsubsection{A cautionary note on theory adoption}

A common theme of the theoretical perspectives discussed is that much of the theory adopted in the triad work is taken from disciplines concerned with interpersonal relationships, rather than inter- 
organizational relationships. However, these theories can provide valuable insights for triad research, especially into both structural and processual issues arising from the triadic form as such. For example, Simmel's work focused on the different roles taken on by the third member in a triad, which may be able to influence and thus explain exchange dynamics. Balance theory emphasizes cognitive consistency among partners, but also acknowledges contingencies (e.g. the exchange process, competition) that may influence the desire for balance in triads. Social network theory with its concepts of strength of weak ties and structural holes further seems promising for triad research. An additional dimension to be considered includes whether triad relationships include commercial exchange, rather than mere interaction.

Overall, while these theoretical perspectives are able to inform triad research, there is also a potential danger in anthropomorphizing organizations when transferring theory between the domains. Similar cautionary advice has been provided concerning such conceptions as 'organizational learning' (Araujo, 1998). Scholars applying these theoretical perspectives, which are inherently grounded in the interpersonal domain, to inter-organizational contexts within triad research, are therefore cautioned to note this potential mismatch, and to apply utmost precision in applying the theoretical notions from above to the environment under study. In addition, influential contingencies that may weaken and strengthen the ability to apply above theoretical perspectives need to be considered; different exchange contexts may demand a combination of theories or an adaptation of the theory to the studied environment.

\section{Features and forms of service triads}

Having delineated the nature of and existing research on service triads, as well as some informing theory, in this section we examine more closely some of the specific issues that arise from the service triad form.

\subsection{Distinctive features of service triads}

In manufacturing supply chains, a component supplier might interact with its customer's customer, but it does not always need to (Figure 3a). And, as in the Choi-Wu studies, supplier-supplier interactions in a potential triad may or may not take place (Figure 2). However, in a service triad, the supplier has to have direct contact with the customer (Figure 3b). Hence, there is a fundamental difference because of the service-based nature of the process and that, at least at the level of the operations process, makes the service triad cohere as a triad. In keeping with this view, Li and Choi (2009) draw on the notion of customer contact (Chase, 1981) as a distinguishing characteristic of services, primarily to demarcate the type of services they wish to study - those involving high customer contact, between supplier and customer. 
Fig 3(a)

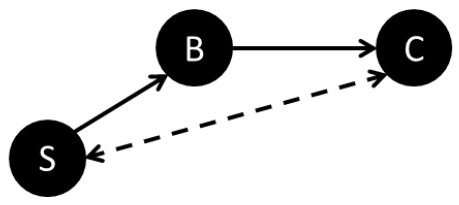

Necessary commercial / contractual relationship

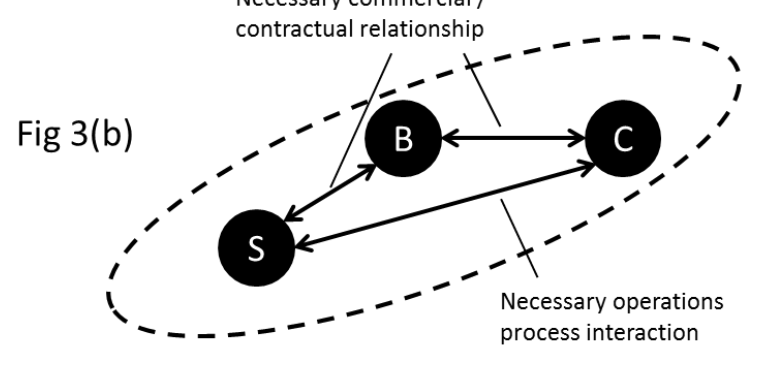

Manufacturing supply chain: discretionary triadic interaction for information exchange

Service triad: necessary triadic interaction in operations process

\section{Figure 3. Comparing buyer-supplier-customer relationships in manufacturing and service}

Furthermore, it is worth recalling that the key task in OM-SCM is to design and manage operations and supply chains to satisfy particular customers with particular products and services, and to achieve certain performance priorities (e.g. Hayes and Wheelwright, 1979, Fisher, 1997). The Choi-Wu studies of supplier-supplier relationships have focused relentlessly upstream, with a view to informing theory and managerial prescription about how firms should manage upstream supply networks (see also Choi et al., 2001), to satisfy the eventual customer. Hence, they study triads implicitly in relation to the customer (Figure 4a), but the customer is not part of the triad. Service triads, in contrast, incorporate the customer as a member of the triad (Figure 4b): in Sampson's terms, the customer is also a supplier (Sampson, 2000) and, hence, designing and managing the supply network (triad) to satisfy the customer, in part, involves managing that same customer's input to and participation in the co-production of the service it pays to receive.

The definition of services, then, becomes important here. Recent developments in both OM and marketing have seen the so-called 'IHIP' characteristics (intangibility, heterogeneity, inseparability, perishability (Sasser et al., 1978, Nie and Kellogg, 1999)) become less widely accepted as a basis for distinguishing between services and products (Lovelock and Gummesson, 2004, Vargo and Lusch, 2004). In their place are two related alternatives. Sampson's unified service theory (UST) is based on defining services as processes to which customers provide significant inputs (Sampson and Froehle, 2006). A second approach, which also hinges on the roles of the respective parties, but is more concerned with ownership of assets than with processes, is what Lovelock and Gummesson term the 'rental/access paradigm', and Spring and Araujo (2009) explain in terms of Coase's notion of the 'institutions of production' (Coase, 1992). Both stress that a service cannot be divorced from an exchange relationship between specific counterparts. 


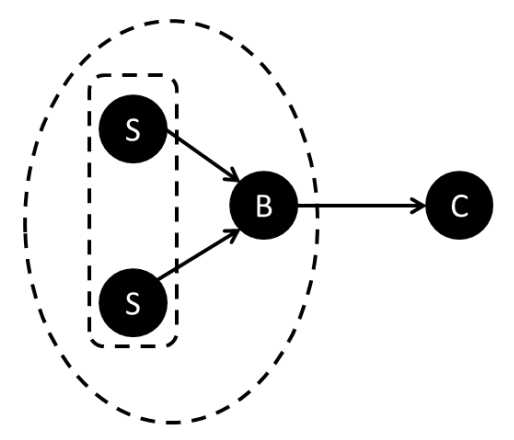

(a) "Triadic sourcing": customer as customer of the triad

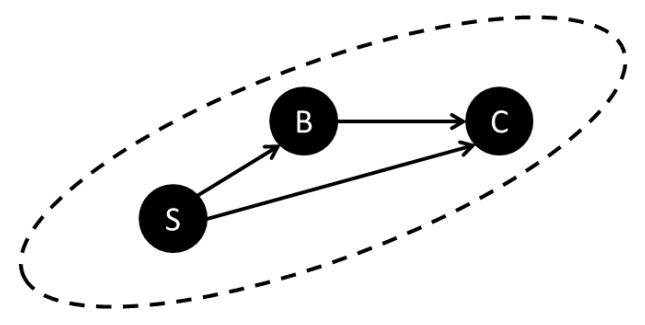

(b) Service triad: customer as part of the triad

Figure 4. The customer's relationship to the triad

An illustrative example may help in exploring these issues. Suppose a truck manufacturer outsources field maintenance of its customers' trucks to a network of third-party maintenance companies. A UST approach would emphasize the importance of the end customer's input into the third-party company's delivery of the maintenance service - by making the truck available and providing information allowing diagnosis and repair, perhaps.

Notice that the customer's role as supplier is potentially split: it might provide some inputs to the buying firm and some to the supplier (Sampson and Spring, 2011). As a consequence, the buying firm may also need to take up a supplier role and provide (i.e. transform and forward) inputs to the supplier ${ }^{5}$. In the triadic setting, this would raise questions about how the buying firm should manage this interactive process: should it obtain diagnostic information from the customer to pass to the maintenance provider, and schedule the maintenance interaction, or should it simply allocate customers to maintenance providers at the outset and then leave all the details to the other two parties to arrange between themselves? The latter scenario may, in the short run, be more efficient for the buying firm, but it may threaten its position to create and claim any value-add in the long run.

The rental/access or institutional approach, in contrast, would emphasize the fact that the thirdparty maintenance company is acting to change the state of something owned by another party (Gadrey, 2000), which has implications for incentives and for the definition of the respective rights

\footnotetext{
${ }^{5}$ In other situations, this supplier role of the buying firm vis-à-vis the supplier is inherently there. Think, for instance, of a situation where a public transport provider outsources cleaning services (of its stations and trains) to external providers. The transport provider will need to manage the adequate supply of inputs (e.g. in terms of volume, timing, location of trains).
} 
and responsibilities. In the triad, questions are raised as to how closely the buying firm should define those roles and responsibilities, as opposed to the maintenance provider. An additional element is introduced when, as is common in this sector, the asset (truck) is not sold to the customer, but is retained in the ownership of the manufacturer as part of a 'servitized' offering. This would give rise to increasingly fragmented rights and responsibilities: the manufacturer owns the truck, the end-user uses it, but the maintenance firm repairs it.

In sum, adopting the UST perspective, a unique feature of service triads is that the inputs for the service process may actually be provided in each of the three relations; the customer may provide inputs both to the supplier and to the buying firm, and the buying firm may provide inputs to the supplier. In adopting the institutional approach, this feature finds its corollary in the fragmented rights and responsibilities between the three actors.

We posit that existing service triad research has not fully leveraged these unique features of service triads. In moving the triad research on to consider service triads, Li and Choi (2009) identify as the key focus of their study the emphasis on the process of outsourcing. This process dimension, however, does not appear to be distinctive for service outsourcing compared to outsourcing manufacturing tasks, whereas the issues arising from the very nature of services are distinctive.

\subsection{Forms of service triads}

There appear to be three main forms of service triads: buyer-initiated triads, customer-initiated triads and supplier-initiated triads (see Table 1). Buyer-initiated triads have their origin in a sourcing or outsourcing decision by the buying firm: for instance, an equipment manufacturer that decides to outsource to a third party the field maintenance of equipment that is operated by its customers, as above. In buyer-initiated triads, the buyer is initially the 'tertius iungens' - the actor who brokers the connection between others ( $\mathrm{Li}$ and Choi, 2009).

Customer-initiated triads have their origin in a decision by the customer to use a third party to mediate and/or support the exchange with a supplier. Imagine, for instance, a customer that uses a project management firm to coordinate and monitor a contractor (or several contractors) that delivers construction work services for a new factory or office building for the customer. Another example from the $\mathrm{B} 2 \mathrm{~B}$ purchasing domain includes the customer contracting with market-making intermediaries that aid the customer in its purchasing decision, for instance by identifying qualified suppliers and conducting negotiations with them.

Finally, supplier-initiated triads have their origin in a decision by the supplier to use a third party to mediate and/or support the exchange with the customer. For instance, an independent truck driver decides to work for a logistics service provider (the buyer), and is during 'service delivery' obviously in direct contact with the provider's customer. 
Table 1. Comparing main types of service triads.

\begin{tabular}{|l|l|l|l|l|l|}
\hline & $\begin{array}{l}\text { Initiating } \\
\text { Party }\end{array}$ & $\begin{array}{l}\text { Focal } \\
\text { service } \\
\text { provider }\end{array}$ & $\begin{array}{l}\text { Service user } \\
\text { (beneficiary) }\end{array}$ & $\begin{array}{l}\text { Providers of } \\
\text { inputs for the } \\
\text { focal service }\end{array}$ & Illustration \\
\hline $\begin{array}{l}\text { Buyer- } \\
\text { initiated }\end{array}$ & Buyer & Supplier & $\begin{array}{l}\text { Customer, } \\
\text { Buyer }\end{array}$ & $\begin{array}{l}\text { Customer, } \\
\text { Buyer }\end{array}$ & $\begin{array}{l}\text { Equipment } \\
\text { manufacturer } \\
\text { outsourcing field } \\
\text { maintenance }\end{array}$ \\
\hline $\begin{array}{l}\text { Customer- } \\
\text { initiated }\end{array}$ & Customer & Buyer & $\begin{array}{l}\text { Customer, } \\
\text { Supplier }\end{array}$ & $\begin{array}{l}\text { Customer, } \\
\text { Supplier }\end{array}$ & $\begin{array}{l}\text { Client firm using a } \\
\text { project management } \\
\text { firm to manage } \\
\text { subcontractors }\end{array}$ \\
\hline $\begin{array}{l}\text { Supplier- } \\
\text { initiated }\end{array}$ & Supplier & Supplier & $\begin{array}{l}\text { Customer, } \\
\text { Supplier }\end{array}$ & $\begin{array}{l}\text { Customer, } \\
\text { Buyer }\end{array}$ & $\begin{array}{l}\text { Small supplier } \\
\text { deciding to operate via } \\
\text { an intermediary }\end{array}$ \\
\hline
\end{tabular}

Table 1. Comparing main types of service triads.

As Table 1 describes, not only the initiating actor may vary - also the actor providing the focal service and the users of this service. In buyer-initiated service triads, not only the customer but also the buyer benefits from the service; for instance, the assets that the buyer uses to service the customer are in a better condition (outsourced cleaning of public transportation). In triads initiated by the customer or the supplier, in contrast, it is typically the supplier (besides the customer) that benefits from the service. Many of these types of triads encompass a supplier getting support from the buyer in accessing and dealing with customers.

As one can deduce from Table 1, buyer-initiated and supplier-initiated triads are quite similar, essentially because in both forms the primary service exchange is between the supplier and the customer. The two types of triads are also similar in terms of the contracts that are most likely to be in place; between the supplier and the buyer, and between the buyer and the customer (see Figure 3b). In some situations, there may also be a supplier-customer contract, for instance if a customer can select a supplier (from a range that the buyer offers). Thus, each of the dyadic relations in buyer-initiated and supplier-initiated triads involves either a contractual relation and/or a service exchange relation. As discussed, Madhavan et al.(2004) refers to such triads as transitive, meaning that all three actors have direct ties with each other.

In the case of customer-initiated triads, where the primary service exchange is between the buyer and the customer, contracts seem most likely for the customer-buyer relation and the customersupplier relation. If there are also contracts in place, or service exchange, between the buyer and supplier, this type of triad would also be transitive.

While this comparison is only a first, somewhat schematic description, it does highlight the importance of specifying the particular triad structure and between whom (exchange) relationships exist, as this will have bearing on the specific interdependencies and OM-SCM processes that will be 
affected by the triad context. Indeed, the presence or absence of contractual relationships and/or service process interactions in each link of the triad will determine the objects of enquiry and the theoretical perspectives used to study service triad phenomena.

\section{Extending service triad research: an agenda}

We see many ways in which the service triad field can be extended as a domain of research. In this section, we seek to identify some dimensions of this extension. First, we discuss some specific topics for service triad research, focusing on OM-SCM related themes. Second, we examine how theoretical approaches from outside and within OM-SCM could help inform alternative research avenues. Finally, we consider the methodological implications arising from the nature of triads.

\subsection{Service triad research topics}

Below is an overview of topics that we believe hold potential for further research on service triads. As argued before, we propose that OM-SCM research on service triads would best be developed further by focusing on OM-SCM themes within triads, rather than identifying interorganizational triads of different supply chain actors and then investigating the classical triad phenomena of the changing positions and roles of the triad actors.

The following overview is not intended as an exhaustive list, but it can serve as a starting point and hopefully provide guidance for researchers interested in other OM-SCM topics to analyze whether and how these could be leveraged within a service triad context. The particular selection of topics raised here has been inspired, partly, by some of our own (ongoing) empirical research, and partly by classical (service) operations and supply chain management research themes (Roth and Menor, 2003). Our suggested topics are in line with the priority themes for research on service networks and value chains, as identified in Ostrom et al. (2010): outsourcing and interorganizational service network collaboration (globally) to enhance service productivity and success; pricing mechanisms to share gains and losses across a service system; and managing upstream and downstream migration in the service value chain.

\subsubsection{Capacity management}

Many service triads involve a buying firm using a specialist provider of 'generic' services, say, call center services. Part of the advantage of this arrangement is that the supplier can pool risk by providing similar services for multiple buying firms and, therefore, to multiple constituencies of end customers. This also enables the supplier to competitively price its services to buyers. However, the supplier has to make decisions about the extent to which staff and processes will be generic and interchangeable between their various customers (maximizing risk-pooling benefits), rather than dedicated to each customer (losing risk-pooling but increasing focus on the end customer group). Hence, an ensuing interesting research question is how much customization of service offerings is 
optimal in service triads, so as to satisfy the buyer and the customer, while minimizing the cost for the supplier (with these cost savings passed on to the buyer). Further, how can the supplier's capacity management be optimized by soliciting input not only from the buyer (who usually provides capacity forecasts), but also from the customer? Within that vein, a question of interest may also be whether and how a supplier, which is part of multiple triads, can leverage its position for efficiencies, potentially also for the benefit of the buyers, who might work together in a co-opetitive framework to further enhance global network performance.

\subsubsection{Risk}

The increased bundling of products and services in service delivery systems, the long-term nature of outsourcing relationships, and the fact that outsourced services are often component services, customized for and delivered directly to the buyer's customer, is reflected in the growing infrastructural and performance complexity of these services (Lewis and Roehrich, 2011). Complexity in terms of infrastructure (ongoing customization, e.g. in terms of timing) and performance (difficulties of assessing and attributing outcomes) can be seen to vary in relation to the type of service being procured. Component services are located at the high end of this complexity spectrum. With this growing complexity and impact of component services on buyer's core business and its final offering to the customer, risk is thus becoming a major concern in outsourcing services (Metters, 2008, Van der Valk et al., 2009, Wynstra et al., 2006).

Studies of risk in supply chain management tended to focus on the identification and mitigation of risks that arise due to factors external to the supply chain (e.g. transportation strikes, terrorism). While these are relevant in service triads, too, a more fundamental question concerns the extent to which, and the ways in which, risks arise from the very structural and dynamic properties of the triadic arrangement. To some extent, risk can be seen as a consequence of other issues we discuss here: perverse incentives in contracts can give rise to undesirable supplier behavior with potential for disproportionately adverse outcomes; poorly understood capabilities can give rise to service quality shortcomings and lost reputation for the buying firm.

With respect to risk management, particular attention could be devoted to triadic relationships that are only incidentally mobilized. Most studies have been concerned with ongoing 'bread-and butter' activities and how they can be accommodated in a triadic structure. Further study is therefore needed into triads that are only called into operation in extreme situations, such as the management and the mitigation of potential disasters (e.g. the 2010 BP oil spill in the Gulf of Mexico). Exciting research questions in this realm include how buyers manage the risk associated with outsourcing service activities to a supplier, with the supplier oftentimes being perceived, by the customer, to be same organization as the buyer. For example, what safeguards are in place, and at what point might it make more sense to insource the service delivery again? 


\subsubsection{Service provider identity and branding}

Buying firms who put their suppliers 'face-to-face' with their end customers have to manage the dynamics of the relationship, as shown by Li and Choi (2009). An interesting perspective on this comes from recent studies of branding and identity in supply chains (Duguid, 2010). Although associated more frequently with consumer markets, brands are important in business markets too, arguably particularly so when complex services are being bought and brand and reputation become important proxies for direct understanding by customers and buying firms alike of the quality of the offering. Duguid's work shows how the location of the most important brands in certain industries shifts over time: one example in the manufacturing industry he explores is the concerted effort Intel made, through the 'Intel Inside' campaign, to ensure that their brand was as prominent as that of the PC assembler's.

Bringing this back to our immediate concern, management by the buying firm of the brands of the respective suppliers is a critical area in delivering a coherent experience to the end customer. For instance, a Dutch insurance company has been collaborating with a supplier of emergency medical and roadside assistance services to develop a smartphone application by which insurance policy holders can call in for assistance. As the insurance company wants to leverage these rare moments for promoting its own brand, an essential element has been the branding of the app.

We posit that service triad research offers fruitful opportunities to extend the work of Duguid and others on branding. Under what conditions, for instance, does branding by the buying organization of the supplier's service help to create a coherent identity of the buying organization's value offerings to customers? Are services that are quite distant from the buying organization's core offering better offered under the supplier's brand, or co-branded by supplier and buyer? Does it matter in this context whether the supplier operates under its own brand in other buyer-supplier-customer triads? Within all of this, how does the relative brand perception of buyer vs. supplier come into play, especially in instances when the brand perception of the supplier is higher than that of the buyer?

\subsubsection{Capabilities}

The resource-based view and capabilities perspectives have increasingly been drawn on to explain the boundaries of firm activities in operations and supply chain management (e.g. Holcomb and Hitt, 2007). The buying firm in a service triad is able to deliver value to its customer by virtue of its own capabilities, and yet for significant elements of the total offering delivered to its customer, it is providing the means for its customer to access the capabilities of its supplier, the third party in the triad. While the buying firm may lack the 'zero-level' capabilities (Winter, 2003) to carry out the service, it does need to have indirect capabilities (Loasby, 1998) so that it can understand and specify the service adequately, taking into account the (technical) requirements of the customer. Studies of the practice of indirect capabilities are rare (although see Spring and Araujo, 2014), but buying firms in service triads must have significant skills in translating between customer and supplier, and 
orchestrating (Hagel and Brown, 2005) possibly multiple third-parties (e.g. consider various component services provided by an airport operator and its passenger customers). One study in point is Parker and Anderson's (2002) investigation of the capabilities required by HP's engineers as they moved into systems integration rather than direct design and production.

With the growing trend towards offering combined product and service systems, buying organizations need to build relations with service suppliers that are increasingly distant from their own core business. Take for instance Volvo Buses, which now needs to build relations with real-estate agents, as well as training and recruitment providers in Asia, to be able to offer complete mobility solutions - including not only buses, but also garage space and trained drivers - to its customers in public transportation.

Service triads set interesting contexts for further studies of indirect capabilities, at buying firms in particular, as they can highlight the role that these capabilities have for the position of the buying firm vis-à-vis the customer as well. Some potential research questions include the following: what is the optimal level of expertise in indirect capabilities from the buyer's perspective? How can indirect capabilities be effectively translated to the supplier? At what point does it make sense to develop these indirect capabilities further and take the service delivery in-house?

\subsubsection{Contracting in triads}

One topic that has rarely been studied in the context of inter-organizational service triads relates to the definition, selection and use of contracts. Organizational theories, in particular agency theory and management control theory, identify two main alternative contract forms: behavior-based contracts and outcome-based contracts (Eisenhardt, 1989, Jensen and Meckling, 1976, Ouchi, 1992). Recently, there has been an increasing interest in outcome-based or 'performance-based' contracts, both in practice and the academic literature (Heinrich and Choi, 2007, Hypko et al., 2010). Traditional management control and agency literature, however, has focused on the context of a dyadic buyersupplier relationship. Little or no research has been done on performance-based contracting in triadic relations, where a buyer contracts with a supplier to deliver services to the buyer's customers (Niranjan and Metri, 2008, Li and Choi, 2009). Co-aligning the interests of buyer, supplier and buyer's customer in performance-based contracts within such triads creates challenges in specifying and controlling performance.

For instance, managing information flows, either to assess behavior or to measure outcomes, becomes a greater challenge to the buying organization ( $\mathrm{Li}$ and Choi, 2009). Service triads would thus also provide interesting settings to study, for instance, the complementarity or substitution effects of contractual and relational governance (Poppo and Zenger, 2002). From a performance-based perspective, it would also be interesting to explore how a supplier may deliver unique insights derived from the interactions with the buyer's customers. Drawing parallels to the manufacturing context, a supplier may be able to provide more to the buyer than the mere fulfillment of the service obligations 
to the buyer's customer. Due to the supplier's interaction with the customers, it may gain valuable intelligence that could help improve the buyer's performance (e.g. unsolicited feedback and suggestions the supplier receives from the buyer's customers).

\subsection{Theoretical perspectives from management and organization}

As in other areas of OM-SCM, service triad research can potentially be strengthened and stimulated by the use of theory from the wider discipline of management and organization studies. Some theories, such as transaction costs economics (TCE) and the resource-based-view (RBV), have become quite widely used in OM-SCM. Some additional theoretical perspectives suggest themselves because of the inter-organizational nature of the triad. Appendix 2 includes a set of theoretical perspectives that may be especially fruitful in their application to service triad research. The selection is derived from our analysis of prior studies on triads (Appendix 1), and the authors' complementary research backgrounds (respectively in service procurement, service operations and supply chain management). Appendix 2 briefly outlines some of the main concepts of the respective theories, as well as how these can be applied to the study of service triads.

The highlighted theories can also help inform some of the research themes identified above. For example, since a supplier depends on the buyer for accurate forecasts to enable efficient capacity management, reciprocal dependence exists between the parties, offering resource dependence theory as a feasible perspective. Similarly, the sharing of information for optimized capacity management can be informed by social network theory, based on which information is passed back and forth between the supplier and the buyer to develop a well-informed capacity plan. Having such a plan in place will lower the risk and cost to the supplier, with the buyer then ideally also receiving the results of these efficiencies in terms of price reductions.

The topic of risk management in service triads can be informed by agency theory, which may help stipulate contractual safeguards to minimize the buyer's risk of being represented by a third party to its customers. Along similar lines, transaction cost economics may be applied to assess whether a triadic structure is most economical (where the service is outsourced, with however the potential for lack of control and thus risk) or a setting where the service is taken back in-house, which may be more expensive, but which may reduce some of the risks of having an independent party perform the service.

Branding and service identity in service triads could be studied from an RBV perspective, where a buyer strategically contracts with a supplier to deliver the service to the customer, due to the supplier's brand reputation. In this instance, this reputation could be classified as a resource, able to differentiate the buyer's overall offering to the customer. Similarly, the theory of performance frontiers may help explain the buyer's rationale for contracting with a highly reputable supplier, so as to enhance the overall value of the offering delivered to the customer, thus pushing performance frontiers outward; this might not have been possible only with the buyer's own resources. 
The topic of capabilities can certainly be studied with the resource- or knowledge-based view of the firm, with supplier capabilities representing valuable resources that can be leveraged by the buyer. The application of TCE also seems promising, since the buyer may need to weigh off whether to have the supplier perform the services (and pay the appropriate service fees), or provide the services itself (which might be more economical in some instances, given the costs of developing and maintaining indirect capabilities, as well as their translation to the supplier).

Agency theory has immediate relevance for the study of contracting in triads, due to its focus on structuring arrangements between entities. Developing appropriate contracts may also be guided by the objective to minimize transaction costs, making TCE a potential framework. Contracting may further bring structure into dependence relationships, thus offering certainty and predictability to important relationships; RDT might therefore also be a feasible foundation.

We have focused this review on the theories that we see as offering the most potential, but the list could be extended to include, for example, capabilities (Loasby, 1998), organizational routines (Feldman and Pentland, 2003), actor-network theory (Latour, 2005), institutional theory (Scott, 1995), power (Clegg et al., 2006), organization design (Srikanth and Puranam, 2010), modularity (Baldwin, 2008) and identity (Gioia et al., 2000), among many others. Beyond the management literature, since service triads often involve extremes of spatial proximity and distance in service delivery, economic geography can also provide interesting insights (Learner and Storper, 2001, Gertler, 2003).

\subsection{Method, theory and the unit of analysis}

Triads in general, and service triads in particular, present special methodological challenges. These concern the links between the theory used, the unit of observation, and the unit of analysis, among others. There is an inherent interdependency between theory and method (Van Maanen et al., 2007, Dubois and Araujo, 2007) in any organizational research, and as we shift our concern from firms to dyads and then triads, this also has implications for the unit of analysis. Many critical insights - for theory and practice - can only be made by changing the unit of analysis, from firm, to dyad and, then, to triad and the extended chain.

Some years ago, Choi and $\mathrm{Wu}$ issued a 'call to arms' (2008, 2009b), exhorting operations researchers to 'take the leap' and study triads rather than buyer-supplier dyads. Different perspectives on the relationship between triads and larger networks led to an exchange between Dubois, and Choi and $\mathrm{Wu}$ in The Journal of Purchasing and Supply Management (Choi and Wu, 2009a, 2009b, Dubois, 2009). Dubois' view, in sum, was that triads are merely an arbitrary subset of larger networks, and that the effect of these networks on firms and dyads can never be escaped (see also Laage-Hellman (1989) and Cova et al. (2010)). Choi and Wu's position is broadly that triads are a distinctive and worthwhile object of investigation in their own right.

In a sense, this tension has run through the various triad studies, as the centrality of the triadic form to the respective studies has waxed and waned, often being more central or essential on account of the 
theoretical perspective being adopted rather than because of any incontrovertible empirical evidence that triadic phenomena have overwhelming explanatory power. The social network theorist Krackhardt summarizes and quotes the seminal theorist of inter-personal triads, Simmel, as follows:

"The difference between a dyad and a triad, however, was fundamental [for Simmel]. Adding a third party to a dyad 'completely changes them, but ... the further expansion to four or more persons by no means correspondingly modifies the group any further' (Simmel, 1950: 138).” (Krackhardt, 1999: 186)

Part of the Choi/Wu-Dubois debate, then, is about whether the shift to triads is indeed fundamental; but Dubois's point is also that, in practice, one can never bound a group of firms whether we choose to examine a dyad or a triad, it will always be connected to and interact with a wider network. Choi and Wu's response (Choi and Wu, 2009a) draws on their conception of supply networks as complex adaptive systems (Choi et al., 2001), arguing that, while the wider network may exhibit emergent properties that will always manifest beyond the triadic level, when it comes to interventions to control the network, the triad can indeed be a powerful unit of analysis and action.

Thus, it is not difficult to see that 'making the leap from dyads to triads' (Choi and Wu, 2009b) is, indeed, a big leap in terms of complexity - if only in terms of data collection. To this we can add some of the practical reality of most organizational research. Survey methods typically collect data from samples of a population of a particular class of firms: in service triads, this might mean firms who are outsourcing their call center operations, for example. It is usually very difficult to collect data from the exact counterpart service providers, although data could be collected from a sample of the population of service providers, and so on. Hence, it is unlikely that reciprocal data could be collected from all the participants in a particular triad (but see Wu et al. (2010) for an instance where this was achieved).

Notice here the interrelationships between phenomenon, the unit of analysis and the theory (both the theory driving the inquiry and the theory that it gives rise to). A relationship is clearly only possible when more than two entities (people or firms) are involved - it is meaningless to speak of a person's relationship as such, it must be its relationship with another; one might then use phenomena observed in a relationship to develop theory about relationships (e.g. weak ties promote radical innovation), or about the entities (e.g. buying firms should maintain arm's length relationships for some kinds of purchased item). Some theories are intrinsically about firms - most obviously, the resource-based view of the firm - but can be used to understand inter-firm issues as, for example, in Holcomb and Hitt (2007) and Dyer and Singh (1998). It could readily be argued that the resourcebased view is inherently relational to some extent anyway, as most of Barney's (1991) VRIN criteria are implicitly about other firms: valuable (i.e. to other firms), rare (i.e. other firms do not have them), inimitable (i.e. by other firms) and non-substitutable (i.e. with resources from other firms). Some IMP writers see the combining of inter-organizational resource as a central issue (Baraldi et al., 2012). 
Figure 5 is an attempt to draw together the elements of the research agenda we have discussed. Overall, it shows the notion of 'theory-driven' research, with an intent to study particular phenomena (service triads), taking explicit account of their defining characteristics, and stimulated by the use of one or more theoretical lenses, perhaps from organizational and operations management origins, perhaps from theories about inter-personal relationships. Data collection will likely be through units of observation at the individual manager or firm level. Nevertheless, there will be an attempt to develop insights about triadic phenomena. Theory development might then concern firms, dyads, triads or, returning to the Choi/Wu-Dubois debate above, the triadic study might be a stepping-stone to theorizing about the wider network.

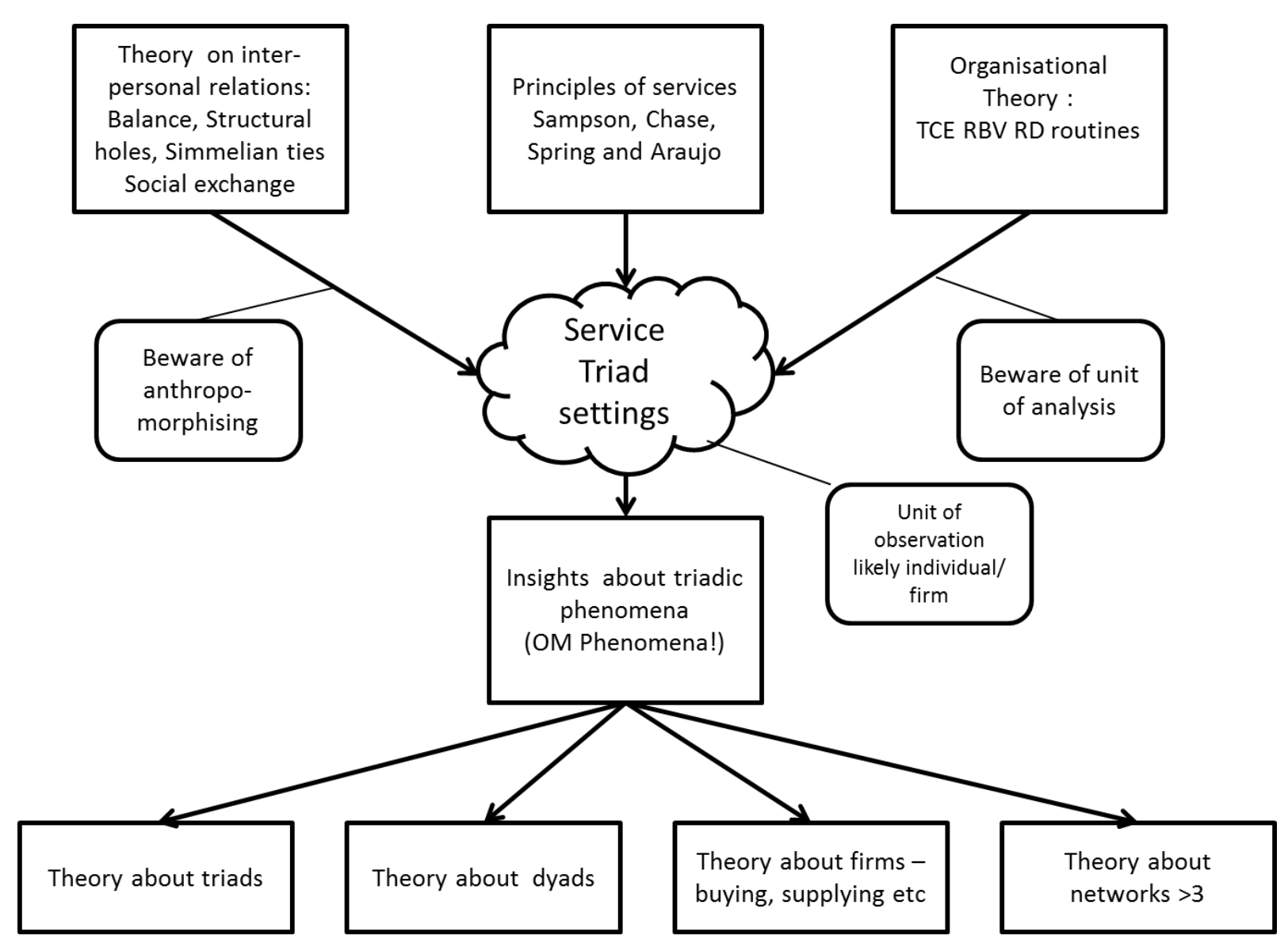

Figure 5. Service triad theory-building

\section{The papers in the special issue}

In total, there are three additional papers in this special issue-resulting from an initial set of 26 submissions.

Modi, Wiles and Mishra examine the consequences for the buyer of service failure by the supplier in service triads. More specifically, they use event study methods to examine the implications of 
customer information security breaches by the supplier. Their study uses service failure and service recovery frameworks, underpinned by social exchange theory, to demonstrate that service failures due to the third party supplier - so-called 'triadic breaches' - lead to greater shareholder losses than breaches due to the buyer, i.e. 'dyadic breaches'. They also hypothesize that buyers with greater employee productivity, and greater financial resources, are better able to mitigate the effects of triadic breaches. They find that, indeed, employee productivity does have such a mitigating effect, but that financial resources do not. This study, rooted in the core operations management concept of service recovery, has important theoretical and practical implications regarding the potential risks associated with outsourcing 'front-end' or component services.

Wuyts, Rindfleisch and Citrin consider the outsourcing of customer support services, and focus on the triadic setting where an outsourcing provider (supplier) serves end customers on behalf of its clients (buyers). Applying a Motivation-Opportunity-Ability framework, the authors hypothesize about effects moderating the relationship between provider customer focus and customer need fulfillment. Contingency variables considered include the relational tie between the client and the provider, the customer focus of the client, and market turbulence. The hypotheses are tested with data from 171 outsourcing clients in the Netherlands, with validation provided by a sample of 135 Indian outsourcing providers. The results provide insight under which conditions provider customer focus more strongly influences customer need fulfillment.

Zhang, Lawrence and Anderson explore one special type of service triad, the franchise triad. This triad can also be seen as a buyer-supplier-customer triad, where the franchisee is the supplier, and the franchisor, as buyer, has outsourced the core, 'front office' service operations to this supplier. Applying Agency Theory, this paper examines the inherent conflict of interests between a principal (i.e., franchisor) that controls brand equity as a shared resource and an agent (i.e., franchisee) that retains pricing rights and profits, by interacting directly with customers. The results demonstrate that franchisees charge higher prices than their corporate counterparts even when controlling for operational performance. The findings suggest that the triad structure plays a significant role in franchisees' ability to free-ride on shared brand equity and hold important managerial implications for effective outsourcing and contract design. The study also provides an interesting perspective on the issue of service provider identity and branding in triads, a topic proposed under our research agenda (section 5).

Together, these contributions span a variety of theoretical frameworks for studying service triads. A common element across all three papers, is that they all focus on the potential risks associated with outsourcing 'front-end' or component services.

\section{Conclusions}

In this lead article, we defined service triads, both as a phenomenon and a research topic. We provided a review of different strands of existing research and various theoretical frameworks that can 
inform our study of service triads, culminating in an outline of a research agenda that can guide future study. The intention of this lead article was thus not only to introduce the articles in the special issue, but also to serve as a point of reference and motivation for further work on service triads, and on triads in general.

Our review culminates in a research agenda, discussed in section 5. Together with these proposed topics, theories and methods, we want to advance three broader recommendations. First, we encourage further development and testing of theories that are finer-grained, and that go beyond analyzing and explaining relationship dynamics within triads. Second, and closely related to the first point, rather than just extending theories of triads, we would suggest to extend theories in triads. In other words, to extend theories dealing with organizational, or dyadic phenomena, to the triadic context.

Thirdly, we suggest extending the number of empirical studies on triads. As noted earlier, triadic studies particularly within OM-SCM (Choi and Wu, 2009b), but also in management research in general (Madhavan et al., 2004), tend to be conceptual in nature. In pursuing such empirical studies, we encourage the application of a more advanced repertoire of research methods for the study of triads than is typically the case so far.

\section{Acknowledgements}

The guest editors sincerely thank the Editors-in-Chief of the Journal of Operations Management, Tom Choi and Dan Guide, for their support of this special issue. We also sincerely thank (in alphabetical order) Linda Hendry, Andi Smart, Merieke Stevens, Morgan Swink, Wendy van der Valk, and Zhaohui $\mathrm{Wu}$, who provided valuable feedback to strengthen and improve earlier drafts of this paper. Finally, we are indebted to the editorial review board for this special issue, individuals which so generously offered their time and energy to review the submissions. The editorial review board consisted of the following individuals (in alphabetical order): Luis Araujo (Lancaster University), Tim Baker (Washington State University), W.C. Benton (The Ohio State University), Joseph P. Cannon (Colorado State University), Christopher Craighead (Pennsylvania State University), Anna Dubois (Chalmers University of Technology), Lisa Ellram (Miami University), Max Finne (Aalto University), John C. Goodale (Southern Illinois University), Dwayne Gremler (Bowling Green State University), Kevin Hendricks (Wilfrid Laurier University), Vaidy Jayaraman (University of Miami), Ahmet Kirca (Michigan State University), Mike Lewis (University of Bath), Mei Li (University of Notre Dame), Saurabh Mishra (McGill University), Sachin Modi (University of Toledo), Gilbert Nyaga (Northeastern University), Serge Rijsdijk (Erasmus University), Aric Rindfleisch (University of Illinois), Claudia Rosales (Michigan State University), Scott Sampson (Brigham Young University), Kostas Selviaridis (Lancaster University), Jeffery S. Smith (Florida State University), Bradley Staats (University of North Carolina), Merieke Stevens (Erasmus University), Wendy Tate (University of Tennessee), Siri Terjesen (Indiana University), Stephan 
Wagner (Swiss Federal Institute of Technology Zurich), Michael Wiles (Arizona State University), Miriam Wilhelm (University of Groningen), Stefan Wuyts (Koç University, Tilburg University). 
Appendix 1: Description of prior triad studies (listed alphabetically)

\begin{tabular}{|c|c|c|c|c|c|c|c|c|}
\hline Publication & $\begin{array}{l}\text { Domain/ } \\
\text { genre } \\
\text { e.g.OM- } \\
\text { SCM }\end{array}$ & $\begin{array}{l}\text { Forms of } \\
\text { triads* } \\
\text { Supplier/ } \\
\text { Buyer/ } \\
\text { Customer }\end{array}$ & $\begin{array}{l}\text { Core theme } \\
\text { e.g. relationship } \\
\text { formation }\end{array}$ & $\begin{array}{l}\text { Theoretical } \\
\text { framework } \\
\text { e.g. structural } \\
\text { holes }\end{array}$ & $\begin{array}{l}\text { Type of } \\
\text { study } \\
\text { Conceptual / } \\
\text { empirical }\end{array}$ & $\begin{array}{l}\text { Methodology } \\
\text { Case study/ } \\
\text { survey / } \\
\text { experiment / }\end{array}$ & $\begin{array}{l}\text { Sector } \\
\text { Manufacturing } \\
\text { / services / .... }\end{array}$ & Contributions/illustrative findings \\
\hline $\begin{array}{l}\text { 1. Andersson- } \\
\text { Cederholm } \\
\text { and } \\
\text { Gyimóthy } \\
(2010)\end{array}$ & $\begin{array}{l}\text { IMP**, } \\
\text { Service } \\
\text { mgt. }\end{array}$ & $\begin{array}{l}\text { S/C (with } \\
\text { two internal } \\
\text { actors) }\end{array}$ & $\begin{array}{l}\text { Illustrating } \\
\text { complexity of } \\
\text { service } \\
\text { interrelations, } \\
\text { illuminating } \\
\text { tensions } \\
\text { and ambivalence }\end{array}$ & $\begin{array}{l}\text { Social network } \\
\text { theory }\end{array}$ & $\begin{array}{l}\text { Conceptual, } \\
\text { with some } \\
\text { empirical } \\
\text { illustrations }\end{array}$ & $\mathrm{NA}$ & $\begin{array}{l}\text { Services } \\
\text { (travel) }\end{array}$ & $\begin{array}{l}\text { Roles, positions and relations } \\
\text { among participants are continuously } \\
\text { (re)defined in a situated social } \\
\text { reality. }\end{array}$ \\
\hline $\begin{array}{l}\text { 2. Bastl et al. } \\
(2013)\end{array}$ & $\begin{array}{l}\text { OM- } \\
\text { SCM }\end{array}$ & $\begin{array}{l}\mathrm{S} / \mathrm{C} / \mathrm{C} \\
\mathrm{S} / \mathrm{S} / \mathrm{C} \\
\mathrm{S} \text { (second } \\
\text { tier)/S/C }\end{array}$ & $\begin{array}{l}\text { Coalition formation } \\
\text { by weaker actors }\end{array}$ & Coalition theory & $\begin{array}{l}\text { Conceptual, } \\
\text { with some } \\
\text { real-life } \\
\text { examples } \\
\end{array}$ & NA & NA & $\begin{array}{l}\text { Propositions on coalition formation, } \\
\text { for the three archetypes of triads, and } \\
\text { four coalition conditions under each } \\
\text { of these. }\end{array}$ \\
\hline $\begin{array}{l}\text { 3. Bjørnevik- } \\
\text { Aune et al. } \\
\text { (2013) }\end{array}$ & IMP & $\mathrm{C} / \mathrm{S} / \mathrm{S}$ & $\begin{array}{l}\text { Activation of third } \\
\text { parties in supplier } \\
\text { development }\end{array}$ & $\begin{array}{l}\text { Industrial } \\
\text { network } \\
\text { approach }\end{array}$ & Empirical & $\begin{array}{l}\text { Multiple } \\
\text { case-study }\end{array}$ & Manufacturing & $\begin{array}{l}\text { Three main forms of 'triadic' } \\
\text { supplier development: indirect and } \\
\text { peripheral; direct and central; direct } \\
\text { and networking. }\end{array}$ \\
\hline $\begin{array}{l}\text { 4. Choi and } \\
\text { Wu } \\
(2009 a, b)\end{array}$ & $\begin{array}{l}\text { OM- } \\
\text { SCM }\end{array}$ & $\begin{array}{l}\mathrm{S} / \mathrm{B} / \mathrm{C} \\
\mathrm{C} / \mathrm{S} / \mathrm{S}\end{array}$ & $\begin{array}{l}\text { Promotion of the } \\
\text { study of triads; } \\
\text { overview of triadic } \\
\text { OM research and } \\
\text { implications }\end{array}$ & $\begin{array}{l}\text { Balance theory, } \\
\text { structural holes }\end{array}$ & Conceptual & $\mathrm{NA}$ & NA & $\begin{array}{l}\text { Argues for triads as the fundamental } \\
\text { building blocks of networks; call for } \\
\text { more triadic research. }\end{array}$ \\
\hline $\begin{array}{l}\text { 5. Choi and } \\
\mathrm{Wu}(2009 \mathrm{c})\end{array}$ & $\begin{array}{l}\text { OM- } \\
\text { SCM }\end{array}$ & $\mathrm{C} / \mathrm{S} / \mathrm{S}$ & $\begin{array}{l}\text { Identification of } \\
\text { nine archetypes of } \\
\mathrm{C} / \mathrm{S} / \mathrm{S} \text { triads in } \\
\text { terms of their } \\
\text { balance }\end{array}$ & $\begin{array}{l}\text { Balance theory, } \\
\text { social network } \\
\text { theory }\end{array}$ & Conceptual & NA & NA & $\begin{array}{l}\text { Develops propositions how the } \\
\text { adversarial or cooperative nature of } \\
\text { relationships within the triad will } \\
\text { have an effect on the other triad } \\
\text { relations, given the state of the triad: } \\
\text { stable/balanced, } \\
\text { unstable/unbalanced, or including a } \\
\text { structural hole. }\end{array}$ \\
\hline $\begin{array}{l}\text { 6. Choi et al. } \\
\text { (2002) }\end{array}$ & $\begin{array}{l}\text { OM- } \\
\text { SCM }\end{array}$ & $\mathrm{C} / \mathrm{S} / \mathrm{S}$ & $\begin{array}{l}\text { Examines three } \\
\text { archetypes of S-S } \\
\text { relationships }\end{array}$ & $\begin{array}{l}\text { Development of } \\
\text { a theory of S-S } \\
\text { relationships }\end{array}$ & Conceptual & NA & Manufacturing & $\begin{array}{l}\text { Illustrates the strategic role of the } \\
\text { buying firm in structuring S-S } \\
\text { relationships; develops propositions }\end{array}$ \\
\hline
\end{tabular}




\begin{tabular}{|c|c|c|c|c|c|c|c|c|}
\hline & & & $\begin{array}{l}\text { (competitive, } \\
\text { cooperative, co- } \\
\text { opetitive) }\end{array}$ & & & & & $\begin{array}{l}\text { on the archetypes' effect on } \\
\text { customer and supplier outcomes; } \\
\text { managerial implications of different } \\
\text { types of S-S relationships. }\end{array}$ \\
\hline $\begin{array}{l}\text { 7. Dubois } \\
\text { (2009) }\end{array}$ & $\begin{array}{l}\text { IMP/OM } \\
-\mathrm{SCM}\end{array}$ & & $\begin{array}{l}\text { Discussion of the } \\
\text { study of triads; } \\
\text { overview of triadic } \\
\text { OM research and } \\
\text { implications }\end{array}$ & $\begin{array}{l}\text { Industrial } \\
\text { network } \\
\text { approach }\end{array}$ & Conceptual & NA & NA & $\begin{array}{l}\text { Argues for the study of triads mainly } \\
\text { as a methodological tool; delineation } \\
\text { of triads versus surrounding network } \\
\text { is often arbitrary. }\end{array}$ \\
\hline $\begin{array}{l}\text { 8. Dubois and } \\
\text { Fredriksson } \\
(2008)\end{array}$ & $\begin{array}{l}\text { IMP/OM } \\
-\mathrm{SCM}\end{array}$ & $\mathrm{C} / \mathrm{S} / \mathrm{S}$ & $\begin{array}{l}\text { Triadic sourcing: a } \\
\text { customer creates } \\
\text { interdependencies } \\
\text { between two } \\
\text { suppliers }\end{array}$ & $\begin{array}{l}\text { Industrial } \\
\text { network } \\
\text { approach }\end{array}$ & Empirical & $\begin{array}{l}\text { Multiple case } \\
\text { study }\end{array}$ & Manufacturing & $\begin{array}{l}\text { Triadic sourcing contributes to the } \\
\text { efficiency and innovation of the } \\
\text { buyer and the two suppliers. }\end{array}$ \\
\hline $\begin{array}{l}\text { 9. Finne and } \\
\text { Holmström } \\
\text { (2012) }\end{array}$ & $\begin{array}{l}\text { OM- } \\
\text { SCM, } \\
\text { Service } \\
\text { ops. mgt. }\end{array}$ & $\mathrm{S} / \mathrm{B} / \mathrm{C}$ & $\begin{array}{l}\text { Possibilities for } \\
\text { subsystem } \\
\text { suppliers to } \\
\text { 'servitize' within a } \\
\text { supply chain, in } \\
\text { which the end user } \\
\text { relationship is } \\
\text { controlled by the } \\
\text { integrator }\end{array}$ & $\begin{array}{l}\text { Service } \\
\text { operations } \\
\text { management }\end{array}$ & $\begin{array}{l}\text { Empirical, } \\
\text { with design } \\
\text { science } \\
\text { approach }\end{array}$ & Case study & $\begin{array}{l}\text { Both } \\
\text { manufacturing } \\
\text { and services }\end{array}$ & $\begin{array}{l}\text { Presents a decision-making } \\
\text { procedure for subsystem suppliers, } \\
\text { opting for cooperation in the service } \\
\text { supply chain, to formulate a coherent } \\
\text { set of triadic models with } \\
\text { intermediaries and end users. }\end{array}$ \\
\hline $\begin{array}{l}\text { 10. Harrison et } \\
\text { al. (2012) }\end{array}$ & IMP & $\mathrm{S} / \mathrm{B} / \mathrm{C}$ & $\begin{array}{l}\text { Triadic dynamics } \\
\text { are considered } \\
\text { through the lens of } \\
\text { roles and positions } \\
\text { in play }\end{array}$ & $\begin{array}{l}\text { Industrial } \\
\text { network } \\
\text { approach }\end{array}$ & $\begin{array}{l}\text { Conceptual, } \\
\text { with } \\
\text { empirical } \\
\text { illustrations }\end{array}$ & NA & Services & $\begin{array}{l}\text { Three triadic scenarios are identified } \\
\text { (diamond, aligned unitary, timer); } \\
\text { how the roles played within the } \\
\text { frame of a triad changes by the } \\
\text { activity task, the counterparts and } \\
\text { time. }\end{array}$ \\
\hline $\begin{array}{l}\text { 11. Havila et al. } \\
\text { (2004) }\end{array}$ & IMP & $\mathrm{S} / \mathrm{B} / \mathrm{C}$ & $\begin{array}{l}\text { Trust and } \\
\text { commitment are } \\
\text { used to study } \\
\text { whether triads are } \\
\text { different from } \\
\text { dyads }\end{array}$ & $\begin{array}{l}\text { Social exchange } \\
\text { theory }\end{array}$ & Empirical & Survey & Manufacturing & $\begin{array}{l}\text { A stronger interaction between the } \\
\text { customer and the buyer weakens the } \\
\text { interaction between the customer and } \\
\text { the supplier; the customer-buyer } \\
\text { relationship influences trust, while } \\
\text { the customer-supplier relationship } \\
\text { influences commitment. }\end{array}$ \\
\hline $\begin{array}{r}\text { 12. Holma } \\
(2012)\end{array}$ & $\begin{array}{l}\text { OM- } \\
\text { SCM }\end{array}$ & $\mathrm{S} / \mathrm{B} / \mathrm{C}$ & $\begin{array}{l}\text { Structural, } \\
\text { relational and }\end{array}$ & $\begin{array}{l}\text { Social network } \\
\text { theory, social }\end{array}$ & Empirical & Case study & $\begin{array}{l}\text { Services } \\
\text { (travel) }\end{array}$ & $\begin{array}{l}\text { Interpersonal interaction takes on } \\
\text { different features each time the }\end{array}$ \\
\hline
\end{tabular}




\begin{tabular}{|c|c|c|c|c|c|c|c|c|}
\hline & & & $\begin{array}{l}\text { cognitive features } \\
\text { of interpersonal } \\
\text { interaction }\end{array}$ & capital & & & & $\begin{array}{l}\text { customer changes the buyer due to } \\
\text { changes in the business environment. }\end{array}$ \\
\hline $\begin{array}{l}\text { 13. Laage- } \\
\text { Hellman } \\
(1989)\end{array}$ & IMP & $\begin{array}{l}\mathrm{S} / \mathrm{S} / \mathrm{B} \\
\mathrm{S} / \mathrm{B} / \mathrm{B} \\
\mathrm{S} / \mathrm{B} / \mathrm{C} \\
\text { Three } \\
\text { additional } \\
\text { forms }\end{array}$ & $\begin{array}{l}\text { Introduces triads as } \\
\text { a first step to } \\
\text { network analysis of } \\
\text { technological } \\
\text { development }\end{array}$ & $\begin{array}{l}\text { Industrial } \\
\text { network } \\
\text { Approach }\end{array}$ & Empirical & $\begin{array}{l}\text { Multiple-case } \\
\text { study }\end{array}$ & $\begin{array}{l}\text { Manufacturing } \\
\text { and services }\end{array}$ & $\begin{array}{l}\text { Technological development requires } \\
\text { mobilization and coordination of } \\
\text { resources and activities of different } \\
\text { actors; focus on triad is primarily a } \\
\text { methodological choice, to help } \\
\text { bridge IMP's subsequent interaction } \\
\text { and network models. }\end{array}$ \\
\hline $\begin{array}{l}\text { 14. Lewis } \\
\text { (2012) }\end{array}$ & $\begin{array}{l}\text { Service } \\
\text { mgt. }\end{array}$ & $\begin{array}{l}\mathrm{S} \text { (with two } \\
\text { internal } \\
\text { actors)/C }\end{array}$ & $\begin{array}{l}\text { Governance } \\
\text { challenges } \\
\text { associated with } \\
\text { knowledge- } \\
\text { intensive service } \\
\text { triads }\end{array}$ & Service & Conceptual & $\mathrm{NA}$ & $\begin{array}{l}\text { Services } \\
\text { (consultancy, } \\
\text { legal etc.) }\end{array}$ & $\begin{array}{l}\text { Suggests alternative levels of } \\
\text { analysis: interpersonal 'micro' triad, } \\
\text { core organizational triad, triad of } \\
\text { knowledge bodies. }\end{array}$ \\
\hline $\begin{array}{l}\text { 15. Li and Choi } \\
\text { (2009) }\end{array}$ & $\begin{array}{l}\text { OM- } \\
\text { SCM }\end{array}$ & $\mathrm{S} / \mathrm{B} / \mathrm{C}$ & $\begin{array}{l}\text { Relation formation } \\
\text { and dissolution in } \\
\text { services } \\
\text { outsourcing triads }\end{array}$ & $\begin{array}{l}\text { Social network } \\
\text { theory }\end{array}$ & Conceptual & $\mathrm{NA}$ & Services & $\begin{array}{l}\text { Loss of the buyer's bridge position } \\
\text { should be mitigated by a bridge } \\
\text { decay arrangement which keeps the } \\
\text { buyer involved in the customer- } \\
\text { supplier exchange. }\end{array}$ \\
\hline $\begin{array}{l}\text { 16. Madhavan } \\
\text { et al. (2004) }\end{array}$ & $\begin{array}{l}\text { OM- } \\
\text { SCM }\end{array}$ & $\mathrm{S} / \mathrm{S} / \mathrm{S}$ & $\begin{array}{l}\text { Drivers of triadic } \\
\text { structure }\end{array}$ & $\begin{array}{l}\text { Structural holes, } \\
\text { network } \\
\text { transitivity }\end{array}$ & Empirical & $\begin{array}{l}\text { Secondary } \\
\text { data analysis }\end{array}$ & Manufacturing & $\begin{array}{l}\text { Firms tend to form transitive triads, } \\
\text { in which all firms have direct ties } \\
\text { with each other. }\end{array}$ \\
\hline $\begin{array}{l}\text { 17. Mena et al. } \\
\text { (2013) }\end{array}$ & $\begin{array}{l}\text { OM- } \\
\text { SCM }\end{array}$ & $\begin{array}{l}\mathrm{S} \text { (second } \\
\text { tier)/S/C }\end{array}$ & $\begin{array}{l}\text { Structure, behavior } \\
\text { and performance of } \\
\text { triads that span } \\
\text { more than two } \\
\text { levels in the supply } \\
\text { chain }\end{array}$ & $\begin{array}{l}\text { (Short review of } \\
\text { different } \\
\text { theories) }\end{array}$ & Empirical & $\begin{array}{l}\text { Multiple case } \\
\text { study }\end{array}$ & Manufacturing & $\begin{array}{l}\text { Propositions on how structural } \\
\text { power, interdependence and } \\
\text { relationship stability are related to } \\
\text { dynamics in the relations in the triad. }\end{array}$ \\
\hline $\begin{array}{l}\text { 18. Menor and } \\
\text { Johnson } \\
(2012)\end{array}$ & $\begin{array}{l}\text { OM- } \\
\text { SCM/ } \\
\text { Service } \\
\text { ops. mgt. }\end{array}$ & $\mathrm{S} / \mathrm{B} / \mathrm{C}$ & $\begin{array}{l}\text { Integrating and } \\
\text { aligning service } \\
\text { operations } \\
\text { management-based } \\
\text { insights with the } \\
\text { operational } \\
\text { workings of service } \\
\text { supply networks }\end{array}$ & $\begin{array}{l}\text { Service } \\
\text { operations } \\
\text { management }\end{array}$ & Conceptual & NA & Services & $\begin{array}{l}\text { Service triad actors need to } \\
\text { understand four critical service } \\
\text { quality functionalities: definition, } \\
\text { design, delivery and diagnosis. }\end{array}$ \\
\hline
\end{tabular}




\begin{tabular}{|c|c|c|c|c|c|c|c|c|}
\hline $\begin{array}{l}\text { 19. Pathak, Wu } \\
\text { and } \\
\text { Johnston } \\
\text { (2014) }\end{array}$ & $\begin{array}{l}\text { OM- } \\
\text { SCM }\end{array}$ & $\begin{array}{l}\mathrm{C} / \mathrm{S} / \mathrm{S} / \\
\mathrm{C} / \mathrm{C} / \mathrm{S} \\
\mathrm{S} / \mathrm{B} / \mathrm{C}\end{array}$ & $\begin{array}{l}\text { Co-opetition in } \\
\text { supply networks }\end{array}$ & Structural holes & Conceptual & $\mathrm{NA}$ & Manufacturing & $\begin{array}{l}\text { As firms within a supply network } \\
\text { interact over time to access, share, } \\
\text { and transform resources, new ties } \\
\text { between firms are formed and } \\
\text { existing ties dissolve, giving rise to } \\
\text { coopetition dynamics at the network } \\
\text { level; definition of supply network } \\
\text { archetypes. }\end{array}$ \\
\hline $\begin{array}{l}\text { 20. Peng et al. } \\
\qquad(2010)\end{array}$ & $\begin{array}{l}\text { OM- } \\
\text { SCM }\end{array}$ & $\mathrm{S} / \mathrm{B} / \mathrm{C}$ & $\begin{array}{l}\text { The effect of triad } \\
\text { structures on } \\
\text { cooperative } \\
\text { performance }\end{array}$ & $\begin{array}{l}\text { Social network } \\
\text { theory }\end{array}$ & Empirical & Case studies & Services & $\begin{array}{l}\text { Firms playing a bridging role } \\
\text { perceive higher cooperative } \\
\text { performance; firms in a peripheral } \\
\text { role experience higher levels of } \\
\text { cooperative performance under high } \\
\text { levels of coordination mechanism } \\
\text { and trust. }\end{array}$ \\
\hline $\begin{array}{l}\text { 21. Raassens et } \\
\text { al. (in press) }\end{array}$ & MKT & $\mathrm{S} / \mathrm{B} / \mathrm{C}$ & $\begin{array}{l}\text { Customer-support } \\
\text { outsourcing, and } \\
\text { differences in their } \\
\text { performance } \\
\text { effects between } \\
\text { suppliers in } \\
\text { emerging markets } \\
\text { vs. established } \\
\text { markets }\end{array}$ & - & Empirical & Event study & Services & $\begin{array}{l}\text { Outsourcing customer support to } \\
\text { emerging markets is less beneficial } \\
\text { for support services that require } \\
\text { direct interaction between customer } \\
\text { and supplier, and highly embedded } \\
\text { knowledge. }\end{array}$ \\
\hline $\begin{array}{l}\text { 22. Shipilov and } \\
\text { Li (2012) }\end{array}$ & $\begin{array}{l}\text { Financial } \\
\text { services }\end{array}$ & $\mathrm{C} / \mathrm{S} / \mathrm{S}$ & $\begin{array}{l}\text { The effect of } \\
\text { customers on the } \\
\text { relationship } \\
\text { between suppliers }\end{array}$ & $\begin{array}{l}\text { (Social network } \\
\text { theory) }\end{array}$ & Empirical & $\begin{array}{l}\text { Secondary } \\
\text { data analysis }\end{array}$ & $\begin{array}{l}\text { Services } \\
\text { (financial } \\
\text { industry) }\end{array}$ & $\begin{array}{l}\text { Vertical ties have a very strong } \\
\text { impact on the formation of } \\
\text { horizontal relationships in triads; } \\
\text { triads are affected by the agency of } \\
\text { customers. }\end{array}$ \\
\hline $\begin{array}{l}\text { 23. Smith and } \\
\text { Laage- } \\
\text { Hellman } \\
\text { (1992) }\end{array}$ & IMP & $\begin{array}{l}\mathrm{B} / \mathrm{S} / \mathrm{S} \\
\mathrm{S} / \mathrm{B} / \mathrm{B} \\
\mathrm{S} / \mathrm{B} / \mathrm{C}\end{array}$ & $\begin{array}{l}\text { The nature and } \\
\text { underlying causes } \\
\text { of connections } \\
\text { between relations } \\
\text { in networks }\end{array}$ & $\begin{array}{l}\text { Industrial } \\
\text { network } \\
\text { approach }\end{array}$ & Empirical & $\begin{array}{l}\text { Single case } \\
\text { study }\end{array}$ & Manufacturing & $\begin{array}{l}\text { A triad is chosen to simplify the } \\
\text { process of analysis, and not defined } \\
\text { as fundamental unit within networks; } \\
\text { identification of five transformation } \\
\text { patterns in triads: by-pass, } \\
\text { combination, bridge, displacement } \\
\text { and separation. }\end{array}$ \\
\hline 24. Tate et al. & OM- & $\begin{array}{l}\mathrm{S} / \mathrm{C}(\text { with } \\
\text { two internal }\end{array}$ & $\begin{array}{l}\text { The influence of } \\
\text { contractual }\end{array}$ & Agency theory & Empirical & $\begin{array}{l}\text { Focus group, } \\
\text { multiple case- }\end{array}$ & Services & $\begin{array}{l}\text { Propositions on the alignment of two } \\
\text { principals (buying function and }\end{array}$ \\
\hline
\end{tabular}




\begin{tabular}{|c|c|c|c|c|c|c|c|c|}
\hline (2010) & SCM & actors) & $\begin{array}{l}\text { agreements on } \\
\text { goals and } \\
\text { behaviors between } \\
\text { the buying } \\
\text { company and the } \\
\text { service provider }\end{array}$ & & & study & (marketing) & $\begin{array}{l}\text { marketing function as internal } \\
\text { customer) within a triadic } \\
\text { relationship with a supplier. }\end{array}$ \\
\hline $\begin{array}{l}\text { 25. Van der } \\
\text { Valk and } \\
\text { Van } \\
\text { Iwaarden } \\
\text { (2011) }\end{array}$ & $\begin{array}{l}\text { OM- } \\
\text { SCM }\end{array}$ & $\mathrm{S} / \mathrm{B} / \mathrm{C}$ & $\begin{array}{l}\text { Designing and } \\
\text { managing contracts } \\
\text { for outsourcing }\end{array}$ & Agency theory & Empirical & $\begin{array}{l}\text { Multiple } \\
\text { case-study }\end{array}$ & Services & $\begin{array}{l}\text { Propositions on the suitability of } \\
\text { outcome- versus behavior-based } \\
\text { contracts, and on the relation } \\
\text { between buyer-supplier and buyer- } \\
\text { customer contracts. }\end{array}$ \\
\hline $\begin{array}{l}\text { 26. Van } \\
\text { Iwaarden } \\
\text { and Van } \\
\text { der Valk } \\
(2013)\end{array}$ & $\begin{array}{l}\text { OM- } \\
\text { SCM }\end{array}$ & $\mathrm{S} / \mathrm{B} / \mathrm{C}$ & $\begin{array}{l}\text { Managing } \\
\text { business-to- } \\
\text { business service } \\
\text { quality in the } \\
\text { triadic context of } \\
\text { outsourced service } \\
\text { delivery }\end{array}$ & $\begin{array}{l}\text { Service } \\
\text { management }\end{array}$ & Empirical & $\begin{array}{l}\text { Multiple } \\
\text { case-study }\end{array}$ & Services & $\begin{array}{l}\text { Propositions on how buying } \\
\text { organizations can control service } \\
\text { delivery in triads. } \\
\text { The buying organization is able to } \\
\text { exert control in other phases than the } \\
\text { service delivery phase. }\end{array}$ \\
\hline $\begin{array}{l}\text { 27. Wu and } \\
\text { Choi (2005) }\end{array}$ & $\begin{array}{l}\text { OM- } \\
\text { SCM }\end{array}$ & $\mathrm{C} / \mathrm{S} / \mathrm{S}$ & $\begin{array}{l}\text { Supplier-supplier } \\
\text { relationships in the } \\
\text { triadic context, and } \\
\text { how it can be } \\
\text { shaped by the } \\
\text { customer }\end{array}$ & NA & Empirical & Case studies & Manufacturing & $\begin{array}{l}\text { Develops eight archetypes, } \\
\text { characterizing the different } \\
\text { approaches of the customers; } \\
\text { develops propositions, most of which } \\
\text { concern supplier-supplier } \\
\text { relationships. }\end{array}$ \\
\hline $\begin{array}{l}\text { 28. Wu et al. } \\
(2010)\end{array}$ & $\begin{array}{l}\text { OM- } \\
\text { SCM }\end{array}$ & $\mathrm{C} / \mathrm{S} / \mathrm{S}$ & $\begin{array}{l}\text { Impact of C/S/S } \\
\text { triads on supplier } \\
\text { performance }\end{array}$ & Game theory & Empirical & Survey & Manufacturing & $\begin{array}{l}\text { Buyers are able to influence the } \\
\text { relational behavior between } \\
\text { competing suppliers; supplier } \\
\text { performance is actually lower when } \\
\text { the level of S-S co-opetition is high. }\end{array}$ \\
\hline $\begin{array}{l}\text { 29. Wuyts et al. } \\
(2004)\end{array}$ & MKT & $\mathrm{S} / \mathrm{B} / \mathrm{C}$ & $\begin{array}{l}\text { Business buyers' } \\
\text { preferences } \\
\text { for specific types } \\
\text { of vertical triads }\end{array}$ & $\begin{array}{l}\text { Social network } \\
\text { theory }\end{array}$ & Empirical & $\begin{array}{l}\text { Conjoint } \\
\text { experiment }\end{array}$ & Manufacturing & $\begin{array}{l}\text { Customers value sequences of } \\
\text { selective strong ties and sequences of } \\
\text { more numerous weak ties; mixed } \\
\text { evidence is found for customers to } \\
\text { value direct access to suppliers when } \\
\text { strong ties exist between the buyer } \\
\text { and suppliers; customers value a }\end{array}$ \\
\hline
\end{tabular}




\begin{tabular}{|c|c|c|c|c|c|c|c|c|}
\hline & & & & & & & & $\begin{array}{l}\text { sequence of strong ties that run from } \\
\text { suppliers through the buyer to the } \\
\text { customer. }\end{array}$ \\
\hline $\begin{array}{l}\text { 30. Yan et al. } \\
\text { (2013) }\end{array}$ & $\begin{array}{l}\text { Human } \\
\text { resources }\end{array}$ & $\mathrm{S} / \mathrm{B} / \mathrm{C}$ & $\begin{array}{l}\text { Relationship } \\
\text { management in the } \\
\text { human resource } \\
\text { outsourcing } \\
\text { network }\end{array}$ & $\begin{array}{l}\text { Social network } \\
\text { perspective, } \\
\text { structural holes, } \\
\text { Simmelian ties }\end{array}$ & Conceptual & NA & Services & $\begin{array}{l}\text { Structural holes and Simmelian ties } \\
\text { enhance HR effectiveness; these } \\
\text { relationships are moderated by HR } \\
\text { task interdependence. }\end{array}$ \\
\hline
\end{tabular}

* We have labeled the actors in terms of our defined three roles, cf. Fig. 1. For instance, we have relabeled a buyer as customer if that was the actor to which the actual goods or service delivery was directed.

** We are defining the IMP Group as a domain by itself, as it has traditionally (and deliberately) spanned various disciplines, such as marketing, operations and international business. 
Appendix 2: Theoretical perspectives for triads

\begin{tabular}{|c|c|}
\hline $\begin{array}{l}\text { Theoretical } \\
\text { perspective }\end{array}$ & Main thoughts \\
\hline Agency theory & $\begin{array}{l}\text { Agency theory deals with the transfer of } \\
\text { work from the principal to the agent, as well } \\
\text { as the ensuing relationship between the two } \\
\text { parties. Agency theory is concerned with } \\
\text { structuring these arrangements so as to } \\
\text { discourage opportunistic behavior in } \\
\text { situations with diverging goals and risk } \\
\text { preferences (Eisenhardt, 1989). These } \\
\text { arrangements include incentive and reward } \\
\text { structures that prevent this behavior from } \\
\text { happening. }\end{array}$ \\
\hline
\end{tabular}

Balance theory Balance theory suggests that individuals seek balanced relationships or 'cognitive consistency' (Kilduff and Tsai, 2003: 42) in their relationships with others. Balance theory rests on reciprocity and the desire that friends are friends with each other.

Knowledgebased view (KBV) of the firm based view (KBV) of the firm suggests that long-term performance advantages are created by firms that best acquire, distribute,
Application to the study of service triads Consistent with agency theory the contractual

arrangements in service triads (where part of the work is transferred to supply-chain service partners) usually focus on collaboration and gain sharing, with both partners committing to common goals. Contracts have the primary purpose of defining incentive and reward structures. This stands in contrast to more power-based and adversarial contracts, mainly focusing on penalty and fine structures.

Triads function best in a balanced state, i.e. when there is agreement among the three members. If unbalance exists, members seek to create balance, according to the theory's structural theorem (Cartwright and Harary, 1956). Using balance theory, relationship formation patterns in triads can be theorized (Choi and Wu, 2009c).

The primary objective of a service triad may be the solicitation or acquisition of knowledge from a third-party, which may have specialized intelligence able to facilitate the exchange between two parties. Knowledge provided can enhance coordination and enable the smooth flow of business.
Representative

articles

Arrow (1971),

Eisenhardt (1989),

Wilson (1968)

Cartwright and

Harary (1956),

Davis (1963),

Heider (1946,

1958), Kilduff and

Tsai (2003)

Dyer and Hatch and use knowledge assets (Grant, 1996).
(2006), Grant

(1996) 
Resource-based view (RBV) of the firm
The resource-based view (RBV) of the firm focuses on the creation and exploitation of unique resources (Barney, 1991, Wernerfelt, 1984). Resources that are valuable, rare, inimitable and non-substitutable, can lead to sustainable competitive advantage, the basic premise of the RBV.

Resource dependence theory (RDT)

Strategic choice theory

Resource dependence theory (RDT) suggests that interdependencies with other firms exist due to one firm's inability to be completely self-sufficient.

Strategic choice theory places emphasis on the key decision makers and attributes their actions to the performance of the firm (Child, 1972). Under this theory, it is not so much the external environment shaping the firm, but the decisions made by company

leadership. Miles and Snow (1978) based their ensuing typology on this contention, and classified decision makers into prospectors, defenders, analyzers and
In service triads, business entities can take advantage of specialized capabilities of third-party service providers. These services offered can represent valuable resources able to differentiate the customer company contracting these services. In addition, having these services performed by specialized providers ensures that the services are performed to high standards (since the provider specializes on these), and that the customer company can focus on its core competencies. The unique combination of customer companies and service providers can represent a resource by itself, as evidenced by the adage 'supply chains competing against supply chains,' instead of 'firms competing against firms'.

Barney (1991),

Wernerfelt (1984)

Pfeffer and

Salancik (1978) relationships due to the unique resources present at each entity. While uncertainty may be reduced through such an arrangement via dedicated relationships, it can also be increased if a client becomes too dependent on the service provider.

Utilizing a service provider in a triadic relationship may represent a proactive stance, with decision makers taking risks and making bold, forward-looking decisions; strategic change is pursued by the disruption of existing routines and social fabrics (a triadic structure may represent such). In Miles and Snow's (1978) framework these are the prospectors, aiming to achieve first-mover advantages by actively managing the transformation. Miles and Snow (2007: 462) observed: "by linking to specialist firms with complementary strategies and capabilities, each
Child (1972),

Miles and Snow (1978) 
reactors, depending on their responsiveness or proactiveness of their decisions.

Social network theory

Theory of performance frontiers

Transaction cost economics (TCE)

\section{Social network theory suggests that} companies strive for closer relationships with supply chain partners when mutual benefits can be achieved. The benefit can derive from strategic interdependencies or

complementarities, or when access to

knowledge, resources, markets or technology is sought.

The theory of performance frontiers distinguishes between the operating and the asset frontiers (Schmenner and Swink, 1998) as representing the firm's constraints. While the former can be altered by more efficient operating choices and approaches within the firm, the latter can be changed by investments in physical assets, technology or human resources. The extension of the operating frontier is constrained by the location of the asset frontier.

Transaction cost economics (TCE) suggests that firms' governance choices should minimize the transaction costs of economic exchange (Williamson, 2008). Generally, TCE considers the three dimensions of asset major competitor in an industry can create its own supply chain". Such specialized firms can be third-party service providers in a triadic exchange.

Service triads seek to utilize external networks for more efficient and effective change. The combination of knowledge and resources of network service partners can lead to mutual gain. Gambardella (1990), Borgatt and Li (2009),

Granovetter

(2005), Gulati (1998, 1998)

Inkpen and Tsang (2005)

The traditional approach to extend the asset frontier is to expend significant capital outlays. However, a firm may also decide to extend their asset frontier via the integration of supply chain service partners, leveraging both their tangible assets and their intangible capabilities, expertise and knowledge. This strategy is less rigid and more flexible since it obviates 'hard' investments; capabilities are available much more quickly, without the need for learning. Extending the frontier via this approach may reap greater benefits.

Transaction costs may be minimized by the employment of service triads, a special form of governance choice.

Williamson $(1985$ Involving a third party in the exchange has the potential to reduce asset specificity (since the third party has to invest in these assets), to yield efficiencies (since the third part
Frohlich and

Westbrook

(2001),

Schmenner and

Swink (1998),

Vastag (2000) 
specificity (i.e., transaction-specific investments), the frequency of transactions, and the environmental uncertainty present in the exchange. may provide similar services for multiple clients), and make the client firm more agile, effectively reducing uncertainty. 


\section{References}

ANDERSON, J. C., HÅKANSSON, H. \& JOHANSON, J. 1994. Dyadic business relationships within a business network context. Journal of Marketing, 58, 1-15.

ANDERSSON-CEDERHOLM, E. \& GYIMÓTHY, S. 2010. The service triad: modelling dialectic tensions in service encounters. The Service Industries Journal, 30, 265-280.

ARAUJO, L. 1998. Knowing and learning as networking. Management Learning, 29, $317-$ 336.

ARORA, A. \& GAMBARDELLA, A. 1990. Complementarity and external linkages: the strategies of the large firms in biotechnology. Journal of Industrial Economics, 38, 361-379.

ARROW, K. 1971. Essays in the theory of risk bearing, Chicago IL, Markham.

AXELSSON, B. \& WYNSTRA, J. Y. F. 2002. Buying business services, Chichester, John Wiley.

BALAKRISHNAN, K., MOHAN, U. \& SESHADRI, S. 2008. Outsourcing of front-end business processes: quality, information, and customer contact. Journal of Operations Management, 26, 288-302.

BALDWIN, C. Y. 2008. Where do transactions come from? Modularity, transactions, and the boundaries of firms. Industrial and Corporate Change, 17, 155-195.

BARALDI, E., GRESSETVOLD, E. \& HARRISON, D. 2012. Resource interaction in interorganizational networks: foundations, comparison, and a research agenda. Journal of Business Research, 65, 266-276.

BARNEY, J. B. 1991. Firm resources and sustained competitive advantage. Journal of Management, 17, 99-120.

BASTL, M., JOHNSON, M. \& CHOI, T. Y. 2013. Who's seeking whom? Coalition behavior of a weaker player in buyer-supplier relationships. Journal of Supply Chain Management, 49, 8-28.

BJØRNEVIK-AUNE, T., HOLMEN, E. \& PEDERSEN, A.-C. 2013. Beyond dyadic supplier development efforts: The multiple roles of the network in bringing about supplier development. The IMP Journal, 7, 91-105.

BORGATTI, S. P. \& HALGIN, D. S. 2011. On network theory. Organization Science, 22, $1168-1181$.

BORGATTI, S. P. \& LI, X. U. N. 2009. On social network analysis in a supply chain context. Journal of Supply Chain Management, 45, 5-22.

BUHMAN, C., KEKRE, S. \& SINGHAL, J. 2005. Interdisciplinary and interorganizational research: establishing the science of enterprise networks. Production and Operations Management, 14, 493-513.

BURT, R. S. 1992. Structural holes: The social structure of competition, Cambridge MA, Harvard University Press.

BURT, R. S. 2002. Bridge decay. Social Networks, 24, 333-363.

CARTWRIGHT, D. \& HARARY, F. 1956. Structural balance: a generalization of Heider's theory. Psychological review, 63, 277.

CHASE, R. B. 1981. The customer contact approach to services: theoretical bases and practical extensions. Operations Research, 29, 698-706.

CHILD, J. 1972. Organisation structure, environment and performance: the role of strategic choice. Sociology, 6, 1-22.

CHOI, T. Y., DOOLEY, K. J. \& RUNGTUSANATHAM 2001. Supply networks and complex adaptive systems: control versus emergence. Journal of Operations Management, 19, 351-366. 
CHOI, T. Y. \& WU, Z. 2008. Taking the Leap from Dyads to Triads: Buyer-Supplier Relationships in Supply Networks. Journal of Operations Management: OSM Forum [Online].

CHOI, T. Y. \& WU, Z. 2009a. Go ahead, leap: Triads and their practical and theoretical import: In response to "To leap or not to leap: Triads as arbitrary subsets of networks of connected dyads" by Anna Dubois. Journal of Purchasing and Supply Management, 15, 269-270.

CHOI, T. Y. \& WU, Z. 2009b. Taking the leap from dyads to triads: Buyer-supplier relationships in supply networks. Journal of Purchasing and Supply Management, 15, 263-266.

CHOI, T. Y. \& WU, Z. 2009c. Triads in supply network: theorizing buyer-supplier-supplier relationships. Journal of Supply Chain Management, 45, 8-25.

CHOI, T. Y., WU, Z., ELLRAM, L. \& KOKA, B. R. 2002. Supplier-supplier relationships and their implications for buyer-supplier relationships. Engineering Management, IEEE Transactions on, 49, 119-130.

CLEGG, S., COURPASSON, D. \& PHILLIPS, N. 2006. Power and organizations, London, SAGE.

COASE, R. 1992. The institutional structure of production. American Economic Review, 82, 713-719.

COOK, K. S. \& EMERSON, R. 1984. Exchange networks and the analysis of complex organizations. Research in the Sociology of Organizations, 3, 1-30.

COVA, B., PRÉVOT, F. \& SPENCER, R. 2010. Navigating between dyads and networks. Industrial Marketing Management, 39, 879-886.

DAVIS, J. A. 1963. Structural balance, mechanical solidarity, and interpersonal relations. American Journal of Sociology, 444-462.

DUBOIS, A. 2009. Comment on "Taking the leap from dyads to triads: Buyer-supplier relationships in supply networks" by Choi and Wu: To leap or not to leap: Triads as arbitrary subsets of networks of connected dyads. Journal of Purchasing and Supply Management, 15, 267-268.

DUBOIS, A. \& ARAUJO, L. 2007. Case research in purchasing and supply management: Opportunities and challenges. Journal of Purchasing and Supply Management, 13, 170-181.

DUBOIS, A. \& FREDRIKSSON, P. 2008. Cooperating and competing in supply networks: Making sense of a triadic sourcing strategy. Journal of Purchasing and Supply Management, 14, 170-179.

DUGUID, P. 2010. Brands in chains. In: LOPEZ, T. D. S. \& DUGUID, P. (eds.) Trademarks, brands and competitiveness. New York, NY: Routledge.138-164

DYER, J. H. \& HATCH, N. W. 2006. Relation-specific capabilities and barriers to knowledge transfers: creating advantage through network relationships. Strategic Management Journal, 27, 701-719.

DYER, J. H. \& SINGH, H. 1998. The relational view: co-operative strategy and sources of interoganizational competitive advantage. Academy of Management Review, 23, 660679.

EASTON, G. \& ARAUJO, L. 1992. Non-economic exchange in industrial networks. In: AXELSSON, B. \& EASTON, G. (eds.) Industrial Networks: A New View of Reality. Routledge, London.62-88

EISENHARDT, K. M. 1989. Agency theory: an assessment and review. Academy of Management Review, 14, 57-74.

FELDMAN, M. S. \& PENTLAND, B. T. 2003. Reconceptualizing organisational routines as a source of flexibility and change. Administrative Science Quarterly, 48, 94-118. 
FINNE, M. \& HOLMSTRÖM, J. 2012. A manufacturer moving upstream: triadic collaboration for service delivery. Supply Chain Management: An International Journal, 18, 21-33.

FISHER, M. 1997. What is the right supply chain for your product? Harvard Business Review, 105-116.

FLOWERS, S. 2007. Organizational capabilities and technology acquisition: why firms know less than they buy. Industrial and Corporate Change, 16, 317-346.

FROHLICH, M. \& WESTBROOK, R. 2001. Arcs of integration:an international study of supply chain strategies. Journal of Operations Management, 19, 185-200.

GADREY, J. 2000. The characterisation of goods and services: an alternative approach. Review of Income and Wealth, 46, 369-387.

GERTLER, M., S. 2003. Tacit knowledge and the economic geography of context, or The undefinable tacitness of being (there). Journal of Economic Geography, 3, 75.

GIOIA, D. A., SCHULTZ, M. \& CORLEY, K. G. 2000. Organizational identity, image and adaptive instability. Academy of Management Review, 25, 63-81.

GRANOVETTER, M. 1973. The strength of weak ties. American Journal of Sociology, 78, 1360-1380.

GRANOVETTER, M. 2005. The impact of social structure on economic outcomes. The Journal of Economic Perspectives, 19, 33-50.

GRANT, R. M. 1996. Toward a knowledge-based theory of the firm. Strategic Management Journal, 17, 109-122.

GULATI, R. 1998. Alliances and networks. Strategic Management Journal, 19, 293-317.

HAGEL, J. \& BROWN, J. S. 2005. The only sustainable edge : why business strategy depends on productive friction and dynamic specialization, Boston, Mass., Harvard Business School Press.

HAVILA, V., JOHANSON, J. \& THILENIUS, P. 2004. International business-relationship triads. International Marketing Review, 21, 172-186.

HAYES, R. H. 2008. Operations management's next source of galvanizing energy? Production and Operations Management, 17, 567-572.

HAYES, R. H. \& WHEELWRIGHT, S. C. 1979. Link manufacturing process and product life-cycles. Harvard Business Review, Jan-Feb, 133-140.

HEIDER, F. 1946. Attitudes and cognitive organization. The Journal of Psychology, 21, 107112.

HEIDER, F. 1958. The psychology of interpersonal relations, New York, Wiley.

HEINRICH, C. J. \& CHOI, Y. 2007. Performance-based contracting in social welfare programs. The American Review of Public Administration, 37, 409-435.

HOLCOMB, T. R. \& HITT, M. A. 2007. Toward a model of strategic outsourcing. Journal of Operations Management, 25, 464-481.

HOLMA, A.-M. 2012. Interpersonal interaction in business triads - Case studies in corporate travel purchasing. Journal of Purchasing and Supply Management, 18, 101-112.

HYPKO, P., TILEBEIN, M. \& GLEICH, R. 2010. Clarifying the concept of performancebased contracting in manufacturing industries: a research synthesis. Journal of Service Management, 21, 625-655.

INKPEN, A. C. \& TSANG, E. W. 2005. Social capital, networks, and knowledge transfer. Academy of Management Review, 30, 146-165.

JENSEN, M. C. \& MECKLING, W. H. 1976. Theory of Firm - Managerial Behavior, Agency Costs and Ownership Structure. Journal of Financial Economics, 3, 305-360.

KILDUFF, M. \& TSAI, W. 2003. Social networks and organizations, London, Sage.

KRACKHARDT, D. 1999. The ties that torture: Simmelian tie analysis in organizations. Research in the Sociology of Organizations, 16, 183-210. 
LAAGE-HELLMAN. 1989. Technological development in industrial networks. University of Uppsala, Sweden.

LARSON, A. 1992. Network dyads in entrepreneurial settings: A study of the governance of exchange relationships. Administrative Science Quarterly, 37.

LATOUR, B. 2005. Reassembling the social: an introduction to Actor-Network-Theory, Oxford, Oxford University Press.

LAZZARINI, S. G., CLARO, D. P. \& MESQUITA, L. F. 2008. Buyer-supplier and suppliersupplier alliances: do they reinforce or undermine one another? Journal of Management Studies, 45, 561-584.

LEARNER, E. E. \& STORPER, M. 2001. The economic geography of the internet age. Journal of International Business Studies, 32, 641-665.

LEWIS, M. \& ROEHRICH, J. 2011. Contracts, relationships, integration: towards a model of the procurement of complex performance. In: CALDWELL, N. \& HOWARD, M. (eds.) Procuring complex performance: studies of innovation in product-service management. New Nork NY: Routledge.21-40

LEWIS, M. A. 2012. Knowledge intensive/professional service triads: preliminary reflections and research options. 4th World Conference Production \& Operations Management. Amsterdam.

LI, M. \& CHOI, T. Y. 2009. Triads in services outsourcing: bridge, bridge decay and bridge transfer. Journal of Supply Chain Management, 45, 27-39.

LOASBY, B. J. 1998. The organisation of capabilities. Journal of Economic Behavior \& Organization, 35, 139-160.

LOVELOCK, C. \& GUMMESSON, E. 2004. Whither services marketing: in search of a new paradigm and fresh perspectives. Journal of Service Research, 7, 20-41.

MABERT, V. \& SCHOENHERR, T. 2001. Evolution of online auctions in B2B eprocurement. PRACTIX, 5, 15-19.

MADHAVAN, R., GNYAWALI, D. R. \& HE, J. 2004. Two's company, three's a crowd? Triads in cooperative-competitive networks. Academy of Management Journal, 47, 918-927.

MENA, C., HUMPHRIES, A. \& CHOI, T. Y. 2013. Toward a Theory of Multi-Tier Supply Chain Management. Journal of Supply Chain Management, 49, 58-77.

MENOR, L. J. \& JOHNSON, P. F. Service operations management and service supply network triadic arrangements. 4th World Conference Production \& Operations Management, 2012 Amsterdam.

METTERS, R. 2008. A typology of offshoring and outsourcing in electronically transmitted services. Journal of Operations Management, 26, 198-211.

MILES, R. E. \& SNOW, C. C. 1978. Organizational strategy, structure and process, New York, McGraw-Hill.

MILES, R. E. \& SNOW, C. C. 2007. Organization theory and supply chain management: An evolving research perspective. Journal of Operations Management, 25, 459-463.

NIE, W. \& KELLOGG, D. 1999. How professors of operations management view service operations. Production and Operations Management, 8, 339-355.

NIRANJAN, T. T. \& METRI, B. A. 2008. CLIENT-VENDOR-END USER TRIAD: A SERVICE QUALITY MODEL FOR IS/ITES OUTSOURCING. Journal of Services Research, 8, 123-138.

OSTROM, A. L., BITNER, M. J., BROWN, S. W., BURKHARD, K. A., GOUL, M., SMITH-DANIELS, V., DEMIRKAN, H. \& RABINOVICH, E. 2010. Moving forward and making a difference: research priorities for the science of service. Journal of Service Research, 13, 4-36. 
OUCHI, W. G. 1992. A conceptual framework for the design of organizational control mechanisms. Management Science, 25, 833-848.

PARKER, G. G. \& ANDERSON, E. G. 2002. From buyer to integrator: The transformation of the supply-chain manager in the vertically disintegrating firm. Production and Operations Management, 11, 75-91.

PATHAK, S. D., WU, Z. \& JOHNSTON, D. 2014. Toward a structural view of co-opetition in supply networks. Journal of Operations Management, 32, 254-267.

PENG, T.-J. A., LIN, N.-J., MARTINEZ, V. \& YU, C.-M. J. 2010. Managing triads in a military avionics service maintenance network in Taiwan. International Journal of Operations \& Production Management, 30, 398-422.

PFEFFER, J. \& SALANCIK, G. R. 1978. The External Control of Organisations: A Resource Dependence Perspective, New York, Harper and Row.

POPPO, L. \& ZENGER, T. 2002. Do formal contracts and relational governance function as substitutes or complements? Strategic Management Journal, 23, 707-725.

RAASSENS, N., WUYTS, S. \& GEYSKENS, I. in press. The performance implications of outsourcing customer service support to service providers in emerging versus established economies. International Journal of Research in Marketing.

ROTH, A. V. \& MENOR, L. 2003. Insights into service operations management: a research agenda. Production and Operations Management, 12, 145-164.

SAKO, M. 2006. Outsourcing and Offshoring: Implications for Productivity of Business Services. Oxford Review of Economic Policy, 22, 499-512.

SAMPSON, S. 2000. Customer-supplier duality and bidirectional supply chains in service organisations. International Journal of Service Industry Management, 11, 348-364.

SAMPSON, S. \& FROEHLE, C. 2006. Foundations and implications of a proposed unified services theory. Production and Operations Management, 15, 329-343.

SASSER, W. E., OLSEN, R. \& WYCKOFF, D. 1978. Management of Service Operations: Text, Cases and Readings, Boston, Allyn and Bacon.

SCHMENNER, R. W. \& SWINK, M. L. 1998. On theory in operations management. Journal of Operations Management, 17, 97-113.

SCHOENHERR, T. \& MABERT, V. A. 2003. A conceptual study of developments in B2B reverse online auctions: the changing role of the online auction provider/intermediary. In: CHIKAN, A. (ed.) Advances in Purchasing and Supply Chain Management.169179

SCOTT, W. R. 1995. Institutions and Organizations, Thousand Oaks, CA, Sage.

SHIPILOV, A. V. \& LI, S. X. 2012. The Missing Link: The Effect of Customers on the Formation of Relationships Among Producers in the Multiplex Triads. Organization Science, 23, 472-491.

SMITH, P. C. \& LAAGE-HELLMAN, J. 1992. Small group analysis in industrial networks. In: AXELSSON, B. \& EASTON, G. (eds.) Industrial Networks: A New View of Reality. London: Routledge.37-61

SPRING, M. \& ARAUJO, L. 2009. Service, services and products: re-thinking operations strategy. International Journal of Operations \& Production Management, 29, 444467.

SPRING, M. \& ARAUJO, L. 2014. Indirect capabilities and complex performance: Implications for procurement and operations strategy. International Journal of Operations \& Production Management, 34, 150-173.

SRIKANTH, K. \& PURANAM, P. 2010. Integrating distributed work: comparing task design, communication, and tacit coordination mechanisms. Strategic Management Journal, 32, 849-875. 
TATE, W. L., ELLRAM, L. M., BALS, L., HARTMANN, E. \& VAN DER VALK, W. 2010. An agency theory perspective on the purchase of marketing services. Industrial Marketing Management, 39, 806-819.

VAN DER VALK, W. \& WYNSTRA, F. 2012. Buyer-supplier interaction in business-tobusiness services: A typology test using case research. Journal of Purchasing and Supply Management, 18, 137-147.

VAN DER VALK, W., WYNSTRA, F. \& AXELSSON, B. 2009. Effective buyer-supplier interaction patterns in ongoing service exchange. International Journal of Operations \& Production Management, 29, 807-833.

VAN IWAARDEN, J. \& VAN DER VALK, W. 2013. Controlling outsourced service delivery: managing service quality in business service triads. Total Quality Management \& Business Excellence, 24, 1046-1061.

VAN MAANEN, J., SÖRENSEN, J. B. \& MITCHELL, T. R. 2007. The interplay between theory and method. Academy of Management Review, 32, 1145-1154.

VARGO, S. \& LUSCH, R. 2004. The four service marketing myths: remnants of a goodsbased, manufacturing model. Journal of Service Research, 6, 324-335.

VASTAG, G. 2000. The theory of performance frontiers. Journal of Operations Management, 18, 353-360.

WERNERFELT, B. 1984. A resource-based view of the firm. Strategic Management Journal, 5, 171-180.

WILLIAMSON, O. E. 1985. The Economic Instituitons of Capitalism: Firms, Markets, Relational Contracting, New York, The Free Press.

WILLIAMSON, O. E. 2008. Outsourcing: transaction cost economics and supply chain management. Journal of Supply Chain Management, 44, 5-16.

WILSON, R. 1968. On the theory of syndicates. Econometrica, 36, 119-132.

WINTER, S. G. 2003. Understanding dynamic capabilities. Strategic Management Journal, 24, 991-995.

WU, Z. \& CHOI, T. Y. 2005. Supplier-supplier relationships in the buyer-supplier triad: Building theories from eight case studies. Journal of Operations Management, 24, 2752.

WU, Z., CHOI, T. Y. \& RUNGTUSANATHAM, M. J. 2010. Supplier-supplier relationships in buyer-supplier-supplier triads: Implications for supplier performance. Journal of Operations Management, 28, 115-123.

WUYTS, S., STREMERSCH, S., VAN DEN BULTE, C. \& FRANSES, P. H. 2004. Vertical marketing systems for complex products: A triadic perspective. Journal of Marketing Research, 41, 479-487.

WYNSTRA, F., AXELSSON, B. \& VAN DER VALK, W. 2006. An application-based classification to understand buyer-supplier interaction in business services. International Journal of Service Industry Management, 17, 474-496.

YAN, M., MARIE FRANCESCO, A., ZHANG, H. \& CHEN, Y. 2013. A social network perspective on relationship management in the human resource outsourcing network: examining the moderating impact of HR task interdependence. Human Resource Management, 52, 585-606. 